\title{
WestVirginiaUniversity
}

THE RESEARCH REPOSITORY @ WVU

Graduate Theses, Dissertations, and Problem Reports

2011

\section{Estonia's Memory Politics in the Context of European Integration}

Marina Suhhoterina

West Virginia University

Follow this and additional works at: https://researchrepository.wvu.edu/etd

\section{Recommended Citation}

Suhhoterina, Marina, "Estonia's Memory Politics in the Context of European Integration" (2011). Graduate Theses, Dissertations, and Problem Reports. 4799.

https://researchrepository.wvu.edu/etd/4799

This Thesis is protected by copyright and/or related rights. It has been brought to you by the The Research Repository @ WVU with permission from the rights-holder(s). You are free to use this Thesis in any way that is permitted by the copyright and related rights legislation that applies to your use. For other uses you must obtain permission from the rights-holder(s) directly, unless additional rights are indicated by a Creative Commons license in the record and/ or on the work itself. This Thesis has been accepted for inclusion in WVU Graduate Theses, Dissertations, and Problem Reports collection by an authorized administrator of The Research Repository @ WVU. For more information, please contact researchrepository@mail.wvu.edu. 


\title{
Estonia's Memory Politics in the Context of European Integration
}

\section{Marina Suhhoterina}

\author{
Thesis submitted to the \\ Eberly College of Arts and Sciences \\ at West Virginia University \\ in partial fulfillment of the requirements \\ for the degree of
}

Master of Arts in History

Robert Blobaum, Ph.D., Chair

Katherine Aaslestad, Ph.D.

Elizabeth Fones-Wolf, Ph.D.

Department of History

\author{
Morgantown, West Virginia \\ 2011
}

Keywords: Estonia; European Integration; the Soviet Union; legacy of communism; Memory Politics

Copyright 2011 Marina Suhhoterina 


\section{ABSTRACT \\ Estonia's Memory Politics in the Context of European Integration}

Marina Suhhoterina

This study examines the process of European integration of Estonia from the perspective of memory politics. The main assumption of the research is that the Estonian political elite often refers to the Soviet past of the country and its reflection in Estonian national memory to frame and guide the political discourse of European integration. In order to test this hypothesis, I analyze the speeches delivered by the leading representatives of the Estonian political elite in the process of post-Soviet transformation. The findings of the study reveal development that is seemingly a paradox. Members of Estonian political elite have attempted to move away from and maintain continuity with the Soviet past at the same time. Politicians present the achievements of their country in the process of European integration as opposed to its Soviet experience, thus stressing the negative side of the latter and emphasizing the European character of Estonia even more. In the process, politicians wish to distance Estonia from its communist past and demonstrate that this period was an aberration for Estonians. At the same time, the Estonian political elite is constantly reminding the international community of the necessity to recognize and condemn the communist crimes as was done with regard to the Nazis immediately after the end of World War II. The findings of my analysis also indicate the gradual change in Estonia's national memory narrative from backward to forward-looking. Estonian politicians wish Estonia to be seen as a European, not post-Soviet country. If in the beginning stages of postcommunist transition the main arguments for this consisted of references to the legal continuity with the First Republic of Estonia that existed in the interwar period 1918-1940, then later stages have been characterized by the replacement of the symbols that glorified the past with the future-oriented image of an innovative nation that can be a model to follow for other European states. 


\section{TABLE OF CONTENTS}

INTRODUCTION

CHAPTER 1: COLLECTIVE MEMORY IN THE CONTEXT OF POLITICAL POWER $\quad 7$

1.1 The Meaning of the Term "Collective Memory" 7

1.2 National (Collective) Memory 11

1.3 Interaction Between Memory and Political Power 14

$\begin{array}{ll}1.4 \text { Methodology } & 17\end{array}$

CHAPTER 2: ESTONIA'S MEMORY IN THE EUROPEAN MNEMONIC

LANDSCAPE $\quad 22$

2.1.1 Memory as a Dividing Line Between Western and Central - Eastern Europe 22

2.1.2 The Patchwork of European Memories 24

2.1.3 Determinants of the European Collective Memory 25

2.1.4 Eastern Enlargement of the EU and European Collective Memory 26

2.2.1 Formation of Estonia's National Memory and History Narrative 28

2.2.2 Russia (the Soviet Union) as a Significant Negative Other for Estonia 30

2.2.3 Europe as a Significant Positive Other for Estonia 31

2.3.1 Estonia's "Returning to Europe"

2.3.2 "Return to Europe" or From "One Union to Another Union"?

2.3.3 Historical Legacies and Memory Framing Estonia's "Return to Europe" 36

CHAPTER 3: REFLECTION OF MEMORY IN POLITICS 41

3.1 Stage I: De-Sovietization 41

3.2 Stage II: Application $\quad 46$

3.3 Stage III: Negotiation 52

3.4 Stage IV: Membership $\quad 62$

$\begin{array}{ll}\text { CONCLUSION } & 70\end{array}$

$\begin{array}{ll}\text { BIBLIOGRAPHY } & 75\end{array}$ 


\section{INTRODUCTION}

Estonia, a small country located in the Northern-Eastern part of Europe on the coast of the Baltic Sea, is one of the former Soviet Republics that entered the European Union (hereafter cited as the EU) in May 2004. Estonia represents an interesting case to examine. The state has undergone very successfully the processes of post-communist transformation and European integration. Estonia has been fairly considered to be the most eager and quick learner of the EU practices and supporter of European ideas. Estonia has the lowest ranks of corruption and highest levels of economic and technological development, characteristics uncommon for the burdened by the Soviet inheritance states. Estonia was

the first among former Soviet Union republics who joined the Eurozone on $1^{\text {st }}$ of January 2011. There has always been a question - what factors determined behaviour of Estonia in the context of European integration. Most common explanations were economic and security rationales. However, there were some other determinants; one of the most important was the Soviet inheritance, its reflection in Estonia's national memory and its role in the formation of the Estonia's European discourse. Historical perspectives on European integration have been paid lesser attention in the literature on this subject. The study is going to fill this gap and demonstrate Estonia's transition from a post-communist to the European country from the point of view of history and memory politics.

The period of existence under the dominance of the communist regime during half of a century is a painful issue for Estonia and Estonians. The Soviet occupation and the whole communist period have always been considered as illegal among the Estonian people. In the collective memory of the nation the Soviet time is reflected as an era of aberration, discontinuity. After restoration of Estonia's independence, the political elite of the country took a straight course directed on fast alienation of Estonia from the Soviet past. On the beginning stage of post-communist transition, the main goal of the political elite was to achieve the international recognition of the Republic of Estonia and assure its security, especially before its biggest neighbour and former oppressor, the Russian Federation, a successor state of the Soviet Union. In order to demonstrate legitimacy of 
their actions, the Estonian political elite resorted most often to the principle of legal continuity with the first Republic of Estonia 1918-1940. By this, political actors wished to distance the country from the Soviet past and move closer to Europe and Western world.

In subsequent years, the Estonian political elite continued its course on rapprochement with Europe. The main direction of discourse remained the same. Estonian political elite wished to replace the "dark" Soviet past of their country with the European present. In order to demonstrate the benefits of potential membership and justify the necessity of joining the EU, the high political representatives often appealed to the national memory to find legitimization to their decisions and foreign policy choices. The recent experience of living under the dominance of the Soviet Union was one of the main elements of the political discourse on European integration. On the one hand, the Estonian political elite always emphasized Estonia's historically determined European, Scandinavian or Nordic character, stressing by this illegality of the Soviet occupation and the whole period of the Soviet rule on Estonia's soil. On the other hand, the Soviet experience was sometimes presented in a context which placed Estonia above other former communist republics as well as non-Soviet states as well. Especially, it was the case when politicians presented achievements of Estonia in different spheres (such as economics, technology, democratic reforms) during the post-communist transition. Parallel to this line of arguments, there has been another - the Estonian political discourse on European integration always contained a demand for international recognition and condemnation of the communist crimes, as it was done right after the War with the Nazis' crimes. The political elite presented it as a necessary precondition for the formation of the strong, stable and united Europe.

The main purpose of the study is to show development of the Estonia's discourse on European integration from the perspective of memory politics. The research is based on the following questions: how the legacies of the Soviet past have influenced Estonia's perception of the EU? How the Estonian political elite have framed the discourse of European integration of the country? Which role does national memory play in that process? How the Estonian politicians deal with national memory to formulate and direct 
the process of European integration?

The study is built on an assumption that the Estonian political elite use the Soviet experience of the country for two separate purposes. On the one hand, emphasizing negative aspects of the Soviet time and contraposing those with Estonia's success and achievements in post-communist transitional period, the Estonian politicians present the Soviet experience as an accelerator of European integration and "Europeaness" of the country. By this, they wish to break away from the Soviet past, to distance as far as possible from it and to replace the Soviet past with European present. On the other hand, the political elite continue to stress the illegality of the Soviet occupation, presenting the Soviet time as an era of aberration for Estonians and demanding international recognition and condemnation of the communist crimes. By this, politicians preserve and maintain the continuity of the Soviet past in Estonia.

The main goal on the study is to control this assumption and find out whether it is justified or not. In order to do that, I examine the speeches delivered by the high representatives of the Estonian political elite in the process of post-Soviet transformation. The analysis is divided into four parts and represents the gradual transition of Estonia from a post-communist state towards a member of the EU: "de-Sovietization," "application," "negotiation," and "membership." The analysis demonstrates the way how the Estonian political elite has formulated and guided the discourse of European integration in the context of historical legacies of the past and national memory. Also, the study reveals different rhetoric methods politicians use in order to legitimize certain political decisions and implied policies. As a result, the analysis demonstrates appeared changes and shifts in the national discourse and explains the prepositions and causes for that.

The study consists of five parts: introduction, the main body divided into three chapters, and conclusion. The chapters are in turn divided into sections. The first chapter develops a theoretical framework for the research introducing the concept of collective memory and its interaction with the political power. The first chapter contains also a 
description of the methodology the study is based on. The second chapter demonstrates the main principles European collective memory and Estonian national memory are built on. The chapter reveals a divergence between European and Estonian memory and explains the main reasons for that. Also, the chapter defines primary historical factors that have influenced the process of European integration of Estonia. The third chapter is analytical; it applies the theoretical framework developed in the previous chapter to the empirical data collected for the analysis. The findings of the analysis demonstrate the mutual dependence of memory and political power and provide the answers to the main research questions and assumptions of the study.

The study is interdisciplinary. It combines examination of two independent concepts, memory and politics, and their interaction. The importance of memory studies is constantly growing and becoming multi-dimensional. In Estonia, the significance of that topic rapidly increased together with the collapse of the Soviet Union. Then, national memory and history that had been suppressed during a half of the century long period were finally unfrozen. A number of historians, political and social science scholars focused their attention on the investigation of memory and its interaction with other disciplines, such as history, culture, social and political sphere. Many academic works were dedicated to the examination of divergence of memories that existed in the Estonian Soviet Socialist Republic during the Soviet time and its influence on the post-communist period. ${ }^{1}$ Kirsti Jõesalu, Ene Kõresaar, Tiina Kirss, Marju Lauristin dealt with the individual memories of the people living in Estonia during the Soviet period and their reflection in subsequent postSoviet era. Yuri Lotman and Marek Tamm approached the topic of memory from the perspective of culture. Due to the fact, that Estonia still has troubled relations and some unresolved issues ${ }^{2}$ with its former oppressor, the successor state of the Soviet Union, the Russian Federation, a lot of academic works have been dedicated to that problem. Maria Mälksoo examined the conflicting memory politics in the Baltic States in the process of European integration focusing on the Soviet inheritance on the one hand and on the current

\footnotetext{
${ }^{1}$ Under the communist regime, the Estonian people (as well as citizens of other former Soviet republics) were forced to adopt a Soviet vision of history and replace national history interpretation by the Soviet.

${ }^{2}$ For example, a question of borders between those two states.
} 
Russian-Estonian relations on the other. Some of the political events of recent years gave an additional impact to investigate the interaction of memory and politics in Estonia. In May 2005, there was a commemoration of the sixtieth anniversary of the end of World War II in Moscow. The leaders of two Baltic States, Estonian President Arnold Rüütel and Lithuanian President Valdas Adamkus, denied an invitation of the Russian President Vladimir Putin to take part in the ceremony. It was a turning point in Estonia's memory politics. Eva-Clarita Onken analyzed this occurrence in her study and demonstrated the consequences it could have for the future. Another important moment in Estonia's memory politics was a relocation of the World War II monument, the "Bronze Soldier," in the Estonian capital Tallinn in August 2007. This incident caused a lot of controversies and fueled fierce discussion in media, politics, public sphere. Many scholars (such as Marko Lehti, Jörg Hackmann, David J. Smith, Alexander Astrov) investigated this topic as well as possible consequences of the incident on Russian-Estonian relations, on the situation with the Russian minority in Estonia, on Estonia's international image.

For the most part, the previously conducted studies on memory politics in Estonia with regards to its Soviet past analyzed the problem in the light of current Russian-Estonian relations. The main focus of this research is the process of European integration of Estonia. The goal of this study is to find out how the Soviet experience has influenced Estonia's position towards Europe and the European Union and how the political elite of the country deal with the Soviet legacies in the process of European integration. In this study, the minimal attention is given to the current Estonian-Russian bilateral relations, though their importance is not underestimated in any way.

The possible limitations of the research are caused by the established page limits for this kind of study. First, I take into consideration only the most important factors, omitting the elements that are out of the focus of the study (though they might seem to be important from the general perspective). Second limitation concerns the empirical data for the analysis. In order to do the research more homogenous, I decided to examine only the speeches and statements that are found directly on the websites of the President of the Republic, the Government, and the Ministry of Foreign Affairs. The spectrum of the 
political figures has also some limitations. The analysis contains only speeches delivered by the Presidents of the Republic, the Prime Ministers and the Ministers of Foreign Affairs in the period 1991-2011 as those actors are the most important representatives of the Republic in domestic and international affairs. Also, they have the biggest influence in the EUrelated decision-making. The research does not include statements made by the members of European Institutions (e.g. the European Parliament) who represent Estonia there since the country joined the EU. Though it may seem important to include them also into the analysis, I prefer not to do it in order to maintain the uniformity of research in the course of all four stages of post-communist transition. 


\section{CHAPTER 1: COLLECTIVE MEMORY IN THE CONTEXT OF POLITICAL POWER}

In the current chapter, I develop a theoretical framework and define the main concepts of the study which are memory and politics. I reveal the meaning of the term "collective memory," demonstrate how memory and political power are related to each other and dependent on each other. The last part of the chapter describes methodology the study is built on. In this part, I explain how I conducted the analysis and dealt with the main research concepts.

\subsection{The Meaning of the Term "Collective Memory"}

As a theoretical term, collective memory was first approached by a French philosopher and sociologist Maurice Halbwachs in 1925. He was the first who juxtaposed individual disciplines of history and memory and developed the concept of collective memory. ${ }^{3}$ Many other scholars based their research on Halbwachs' assumptions and arguments. Nowadays, there are thousands of articles and other academic works on the topic which shows its continuing relevance. ${ }^{4}$

Due to its ambiguity and multisided nature, there is no single definition of the concept "collective memory." Aleida Assmann argues that it is too vague to serve as a critical term. ${ }^{6}$ She suggests to define it through the functions collective memory plays in society; as an "umbrella term for different formats of memory that need to be further distinguished."7 Assmann develops four main categories, or formats of memory, that allow to classify and range different types of memory (such as individual, family, social, political,

\footnotetext{
${ }^{3}$ Marek Tamm, "History as Cultural Memory: Mnemohistory and the Construction of the Estonian Nation," Journal of Baltic Studies 39 (2008): 500.

${ }^{4}$ William Hirst and David Manier, "Towards a Psychology of Collective Memory," Memory 16 (2008): 183.

${ }^{5}$ The concept "collective memory" has been used in many fields: psychology, anthropology, history, political and social science.

${ }^{6}$ Hirst and Manier, 184.

${ }^{7}$ Aleida Assmann, “Transformations Between History and Memory,” Social Research 75 (2008): 55.
} 
national, cultural, interactive group memory). These formats involve individual, social, political, and cultural memory; among them, three latter formats are components of collective memory. ${ }^{8}$ Individual and social memories are short-term, and disappear together with their carriers. On the contrast, political and cultural memories are long-term, based on the more durable carriers of external symbols and representations. In order to transform short-term memories into long-term and transfer them thereafter from generation to generation, short-term memory has to be organized and institutionalized. The main means for that include formation of mobilizing narratives; various visual and verbal signs that serve as aids of memory; creation of the institutions of learning and the dissemination of mass media; erection of sites and monuments of remembrance, and organization of commemoration rites and other practices to reactivate the memory and enhance collective participation. All those means serve to transform implicit, heterogeneous, fuzzy bottom-up memory into explicit, homogenous, institutionalized, formalized top-down memory. ${ }^{9}$ Based on simplified version of own categorization, Aleida Assmann distinguishes also two forms of participation in collective memory: informal social memory and the more formal and organized political memory. Transition from social to political memory appears when "abstract and generalized "history" turns into re-embodied collective "memory", when it is transformed into forms of shared knowledge and collective participation." ${ }^{10}$ Those two features [shared knowledge and collective participation] are thus the main elements of long-term political memory. As a result of that process, "history in general" becomes not only emotionally coloured "our history," but also a part of collective identity.

Typology of collective memory by Jan Assmann is rather different. He distinguishes between material, mimetic, communicative, and cultural memory. ${ }^{11}$ Similarly to Aleida Assmann, Jan Assmann also refers to short- and long-term memory and transmission from one level to another. In his analysis, the short-term applies to communicative and long-term

\footnotetext{
${ }^{8}$ Aleida Assmann, "Four Formats of Memory: From Individual to Collective Constructions of the Past" in Cultural Memory and Historical Consciousness in the German-Speaking World Since 1500 (Papers from the Conference "The Fragile Tradition," Cambridge 2002. Volume 1), ed. by Christian Emden and David R. Midgley (Oxford: P. Lang, 2004), 22.

9 A. Assmann, 2008, 55-56.

${ }^{10}$ A. Assmann, 2008, 65.

${ }^{11}$ Material memory, based on objects; mimetic memory, based on imitation; communicative memory, based on oral discussion; and cultural memory, based on written and visual carriers of information (Tamm, 500).
} 
- to cultural memory. Wulf Kansteiner agrees with Jan Assmann's classification and juxtaposition of communicative and cultural memory. He complements Assmann's definition of cultural memory that "serves to cultivate and convey society's self-image" with own arguments. According to Kansteiner, the elements of cultural memory, such as texts, rites images, buildings, monuments, "are designed to recall fateful events in the history of the collective." 12

Another crucial moment in the study of collective memory is a role of individual memories. Is it justified to consider collective memory as a set of organized individual memories which would allow to regard individual memories also as a part of collective? According to Irwin-Zarecka, it is not: collective memory is not "a collection of individual memories or some magically constructed reservoir of ideas and images, but rather a socially articulated and socially maintained "reality of the past." ${ }^{13} \mathrm{~J}$. Assmann's distinction between communicative and cultural memories also refers to his tendency to locate collective memories outside the individual. ${ }^{14}$ William Hirst and David Manier do not deny the importance of individual memories in formation of collective; however, similarly to A. Assmann they emphasize first, the shared character of them, and second, the element of identity: "we have treated collective memories as shared individual memories that shape collective identity." 15 Duncan Bell also pays special attention to the notion of "shared," opposing that kind of memory to "common" memory. ${ }^{16}$ Bell defines the latter as "the sum of the total number of memories of an event within a community, and it does not require communication or generate intersubjective meanings." On the contrast, shared memory relies on communication in order to fulfill its main goal - integration and calibration of different memories of people about a particular event or episode into one version. Kansteiner also emphasizes the element of "shared communications about the meaning of

\footnotetext{
${ }^{12}$ Communicative memory in Jan Assmann's approach is reduced to everyday communication about the meaning of the past; communicative memory duration is limited by 80-100 years; it is disorganized, unstable, and strongly influenced by contemporary events (Jan Assmann, "Collective Memory and Cultural Identity" in New German Critique 65 (1995): 132; see also Wolf Kansteiner, "Finding Meaning in Memory: A Methodological Critique of Collective Memory Studies," History and Theory 41 (2002): 182).

${ }^{13}$ Iwona Irwin-Zarecka, Frames of Remembrance: the Dynamics of Collective Memory (New Brunswick [N.J.]: Transaction Publishers, 1994), 54.

${ }^{14}$ Hirst and Manier, 185.

${ }^{15}$ Hirst and Manier, 196.

${ }^{16}$ Duncan Bell, "Agonistic Democracy and the Politics of Memory," Constellations 15 (2008): 155.
} 
the past" in construction of collective memory. ${ }^{17}$ Olick suggests that in order to be treated as "collective," but not just "collected" memory, it first, has to be widely held by members of a community, and second, it should be really meaningful for them. ${ }^{18}$

As A. Assmann points out, the step from individual memories towards shared collective memory can not be regarded as an easy analogy. Collectives, communities, as well as other larger social groups (nations, states) and different institutions those social groups belong to (political, governmental, religious, private) do not really "have" a memory, they "make" one for themselves with the help of various components, or signs, of memory such as symbols, ceremonies, rituals, monuments. ${ }^{19}$ In that sense, among abovementioned formats of memory political memory seems to be the most "collective" as it not only generates a meaning of particular facts, but does it together with a sense of loyalty and a strongly unifying "we-identity." 20 As Eva-Clarita Onken argues, such collective identity does not need anymore the actual historical circumstances surrounding experiences of a group of people (a nation) to survive and develop. Rather, those experiences create a ground for formation of simplified narratives and myths of the political community that transcend the lifetime of individuals and even generations. Thus, from short-term, memories transform into long-term and become institutionalized. This process influences not only interpretation of the past events, but also prescribes the way of understanding the present and future.

Abovementioned chain of transformations from individual to collective political memory demonstrates the relevance of latter for a larger society. Further, I show the functioning of political memory on the national level and reveal its influence and interconnection with identity formation as well as the role of political memory in domestic and foreign decision-making processes.

\footnotetext{
${ }^{17}$ Kansteiner, 188.

${ }^{18}$ Jeffrey K. Olick, “Collective Memory: The Two Cultures,” Sociological Theory 17 (1999): 343; see also Kansteiner, 186.

${ }^{19}$ A. Assmann, 2004, 25-26.

${ }^{20}$ Eva-Clarita Onken, "Memory and Democratic Pluralism in the Baltic States - Rethinking the Relationship," Journal of Baltic Studies 41 (2010): 280-281.
} 


\subsection{National (Collective) Memory}

Interaction between memory, identity formation and politics on national level demonstrates the complex relation between short-term social and long-term political memory. National collective memory is shared by individuals and institutionalized by a state. It not only defines national identity, but also fosters cohesion within a nation and prescribes its action. $^{21}$

At national level, there are two main types of collective memory. Heiko Pääbo refers to them as primary and mediated memory; Jan-Werner Müller defines them as mass individual memory and national memory; Timothy Snyder distinguishes between "mass personal memory" on the one hand, and a sort of a principle to "organize the history" on the other. ${ }^{22}$ The former is the recollection of events by a number of individuals in which they have actually participated and lived through. The latter is a framework through which "nationally conscious individuals can organize their history." Müller claims that it is possible to regard the second type of collective memory as a myth; however, he admitted that such approach might be misleading. ${ }^{23}$

The main focus of my study is on the second type of national collective memory, which is "mediated," directed on the "organization of history." This memory is based on and functions through national history narratives, or nations' master narratives. The master narrative shapes nation's collective memory; it binds the elements stored in memory into one meaningful sequence. ${ }^{24}$ National narrative serves as a bridge between past and present, past and future, as well as present and future. It enables people to understand the past of their nation, providing necessary explanations for the past events and their reflections and

\footnotetext{
${ }^{21}$ Heiko Pääbo, Potential of Collective Memory Based International Identity Conflicts in Post-Imperial Space. Comparison of Russian Master Narrative with Estonian, Ukrainian and Georgian Master Narratives (Tartu: Tartu University Press, 2011), 33.

${ }_{22}$ Pääbo, Potential of Collective Memory Based International Identity Conflicts in Post-Imperial Space, 33; Jan-Werner Müller, ed., Memory and Power in Post-War Europe Studies in the Presence of the Past (Cambridge: Cambridge University Press: 2002), 3; Timothy Snyder, "Memory of Sovereignty and Sovereignty Over Memory: Poland, Lithuania and Ukraine, 1939-1999" in Memory and Power in Post-War Europe: Studies in the Presence of the Past, ed. by Jan-Werner Müller (Cambridge: Cambridge University Press, 2002): 39.

${ }^{23}$ Müller, 3.

${ }^{24}$ Tamm, 502-505.
} 
connections with the present and future. ${ }^{25}$ Besides mnemonic functions, national history narratives are also involved in reproduction of the national identity and nation-building, telling a story "which depicts the nation as a unified group moving through history, even in the case if it does not fully correspond to the reality." ${ }^{26}$ The narrative provides nation's past with coherence; it presents nations as an entity with unified destiny and interests; it also establishes a boundary between members and non-members, between those sharing the common past and those who do not. ${ }^{27}$ The portrait of the nation created by the narrative might be distorted and misleading, even if the events and evidence they are based on are truthful. $^{28}$

An important role in formation of the national history narrative, as well as construction of the nation and national identity plays conceptual pair of Self and Other. Duncan Bell claims that while acting together, Self and Other, or us and them, create a "mutually supporting scaffolds" for national identity construction. ${ }^{29}$ Some scholars, such as Göran Therborn and Emmanuel Lévinas, demonstrate even higher relevance of the concept of Other than Self in that process. The former argues that "there is a primacy of otherness over sameness in the making of identity." 30 The latter presents an image of Self as derivative from the appearance of Other, claiming that the face of Other calls the Self into existence. ${ }^{31}$ Lévinas emphasizes the exteriority and alterity of Other with regards to Self, referred to the relationship between Self and Other as a Mystery. However, at the same time he stresses that there is a resemblance between Self and Other, "one is for the other what the other is for oneself," "the other is known through sympathy, as another (my)self, as the alter ego." 32

However, there is also an opposite viewpoint on Self/Other nexus. If Lévinas

\footnotetext{
${ }^{25}$ Rogers M. Smith, Stories of Peoplehood: the Politics and Morals of Political Membership (Cambridge: Cambridge University Press, 2003), 64-65.

${ }^{26}$ Pääbo, Potential of Collective Memory Based International Identity Conflicts, 39.

${ }^{27}$ Tamm, 502; Pääbo, Potential of Collective Memory Based International Identity Conflicts, 40.

${ }^{28}$ Pääbo, Potential of Collective Memory Based International Identity Conflicts, 39.

${ }^{29}$ Duncan Bell, "Mythscapes: Memory, Mythology, and National Identity," British Journal of Sociology 54 (2003): 67.

${ }^{30}$ Göran Therborn, European Modernity and Beyond: the Trajectory of European Societies, 1945-2000 (London: Sage Publications, 1995), 229.

${ }^{31}$ Iver B. Neumann, Uses of other: "The East” in European Identity Formation (Manchester: Manchester University Press, 1999), 16.

${ }^{32}$ Emmanuel Lévinas and Seán Hand, The Levinas Reader (Oxford: Blackwell, 1989), 47.
} 
presents Other "as something on the order of an angel," some scholars suggest that Other seem to be hell. ${ }^{33}$ Another perspective to regard interaction between Self and Other is to contrast them, most commonly as "positive Self vs negative Other" and/or "the Other is what I myself am not." ${ }^{34}$ Such viewpoint is widespread in international relations, nationalism and identity studies. According to Pääbo, in the process of construction of national identity Self needs Other that is the mirror-image to Self. ${ }^{35}$ In case of newly established or newly independent states that had an experience of foreign dominance, the contraposition of Self against Other is especially evident. The narratives about heroic struggle of formerly suppressed nations (positive Self) against their external ruler (negative Other) justify their "historical duty to live freely and to be sovereign." 36 Violence of the past, often presented as "victimization" of the nation finds its reflection in national narratives. In some cases victimization may have a greater impact on strengthening of national identity, rather than on glorifying past narratives. ${ }^{37}$ Also, such way of construction of a nation is very selective. Usually, only the episodes that support the positive image of Self are included into the national narrative. What does not maintain the heroic pattern is passed over and forgotten. ${ }^{38}$ Also, A. Assmann makes an important remark about being a victim as a result of defeat or trauma. The scholar claims that the concept of trauma can not be integrated into a heroic narrative since it "threatens and shatters the constitution of a vigorous self-image," "trauma is the other of heroic narrative." 39

Another controversial moment with regards to the Self/Other nexus is a multiplicity of Others. Lévinas sees it as a problem, questioning what to do in case of many Others, how to define the concept of Other in general and understand who is the closest Other to

\footnotetext{
${ }^{33}$ Neumann, 23.

${ }^{34}$ Neumann, 17.

${ }^{35}$ Pääbo, Potential of Collective Memory Based International Identity Conflicts, 41.

${ }^{36}$ Pääbo, Potential of Collective Memory Based International Identity Conflicts, 42.

${ }^{37}$ Pääbo, Potential of Collective Memory Based International Identity Conflicts, 42.

${ }^{38}$ A. Assmann, 2004, 26.

${ }^{39}$ Assmann, distinguished between being defeated in history and being a victim of history. An example in the first case might be victims of war who actively resisted their enemy, but still were defeated. The second case refers to those who by historical coincidence were exposed to violence and sufferings without any means to resistance and self-defence. Respectively, if in the former case sufferings or death of victims might be presented as a heroic act of martyrdom or sacrifice, no heroic memory could be constructed in the latter case (A. Assmann, 2004, 28).
} 
Self. $^{40}$ On the contrary to Lévinas, Pille Petersoo does not see any obstacle with the multiplicity of Others, considering it rather as a normal state of affairs. Petersoo introduces four "ideal types" of Other: internal positive Other, internal negative Other, external positive Other, external negative Other, claiming that several Others can coexist at the same time. $^{41}$

The interaction between concepts of Self and Other plays an important role in the formation of national memory and national identity. It has an influence on past and present, and interpretation of different events. In further chapters I demonstrate the impact and reflection of the nexus Self/Other in the process of political decision-making.

\subsection{Interaction Between Memory and Political Power}

As interaction between memory and political power, as well as reflection of memory in politics is in the focus of this study, it is necessary to clearly define the relation between those two concepts. Heidemarie Uhl suggests an idea to regard memory as politics in order to understand the potential influence of these phenomena on each other. ${ }^{42}$ As noticed above, Aleida Assmann distinguishes between bottom-up social and top-down political memory which allows her to reveal penetration, transformation and functioning of different kinds of memory on the political level.

Eva-Clarita Onken demonstrates four primary ways how memories can be manifested in the public-political sphere. ${ }^{43}$ First, in the form of political measures which explicitly deal with the past through justice and accountability policies. One of the preconditions for that form of manifestation is a change of political regime in the country which may also cause a replacement of old political elites by new. Under these conditions, political actors apply to various legislative practices with a purpose to establish a particular

\footnotetext{
${ }^{40}$ Lévinas and Hand, 247.

${ }^{41}$ Pille Petersoo, "Reconsidering Otherness: Constructing Estonian Identity," Nations and Nationalism 13 (2007): 121.

${ }^{42}$ Heidemarie Uhl, "Memory Culture - Politics of History. Some Reflections on Memory and Society" in Politics of Collective Memory: Cultural Patterns of Commemorative Practices in Post-War Europe, ed. by Sophie Wahnich, Barbara Lášticová, and Andrej Findor (Berlin: Lit, 2008), 61.

${ }^{43}$ Eva-Clarita Onken, Forms of Collective Memory and How They Relate to Power, Identity and Myth (a lecture at Winter school on Politics of Memory, February 27 - March 1), Tartu: 2008.
} 
interpretation and evaluate what was right or wrong under the previous regime.

Another clear case of political memory are public speeches and statements by high representatives of political elite (heads of states and government) in which they create historical analogies to the past in order to justify or legitimize current policies. In their speeches, political actors use different rhetoric methods combined with sonorous arguments and justification to certain political decisions which allows them to create an appropriate framework and provide some "guidelines" how the past is "officially" remembered.

The third form of manifestation of memory in the political sphere are public representations and rituals, or material and procedural symbolic forms of commemoration, as A. Assmann also classifies them. ${ }^{44}$ The former includes the erection of monuments, naming the streets, schools, and other public institutions, foundation of museums. The latter represents various ceremonies, rituals and practices of commemoration, as public burial rites for example. By the means of such symbolic attention, the political elite together with some other state actors and non-governmental agents can control and direct the ways how the past is understood and interpreted, how past events are remembered and commemorated. ${ }^{45}$ Politicians are in charge of establishing particular traditions and events of commemorations, and national anniversaries. Similarly to the mnemonic manifestations in high politics, public representations and rituals also allow political elite to establish a way the past is remembered as well as to guide the whole process of remembrance.

Three abovementioned cases demonstrate the top-down approach to regard the nexus between memory and politics. There is also other way to examine relationship between these two concepts, from the perspective of bottom-up memory. It is the fourth form of Onken's classification. The author distinguishes different ways how social groups may assert their influence in the public-political sphere. One of them appears when various groups (such as ethnic and religious minorities, certain professional communities, war veterans), who have particular interpretation of the past, feel that their memories are being mis- or underrepresented in official narratives and policies. ${ }^{46}$ In order to achieve

\footnotetext{
${ }^{44}$ A. Assmann, 2004, 24.

${ }^{45}$ In his article, Tamm defined the actors involved in the memory work as six P's: priests, professors, PR specialists, politicians, poets and publicists (Tamm 2008, 502).

${ }^{46}$ Onken, 2010, 283.
} 
recognition and acknowledgement of their interpretation of the past on the state level (through symbolic politics, apologies) these social groups seek for opportunities to represent their interest in the democratic state institutions and procedures. For instance, they may find some mediator from the political world who would not only represent their interests, but also contribute to the inclusion of their memories into the national political memory. Another way is active lobbying among policy makers with the aim to change public perceptions and/or legislation and incorporate their experiences into the public discourses. One more possibility is a direct participation of some representative of a social group with particular memories in decision-making process and construction of political memory of the state. These examples show that memory can influence and create a basis for political and group identities among different interest groups which may be translated into political action and direct participation. In some cases, as a result of such activity, bottom-up social memory transforms into top-down political memory.

The main focus of this study is manifestation of memory on the level of high politics. In order to examine this interaction, I rely on theoretical assumptions developed by Müller. The latter suggests to regard memory as a power, whether "symbolic" or "structural." Such conceptualization allows him to examine how memory is involved in the process of policy-making both in terms of construction and legitimization of foreign policies as well as the contestation of domestic politics. ${ }^{47}$

Legitimacy is the primary link that connects memory and political power. Policies are justified through appeals to the collective or national memory and legitimized on the grounds of historical experience. ${ }^{48}$ Such "mnemonic legitimation" can be based on both: continuity as well as on a break with the past. ${ }^{49}$ Usage of national history narrative and myths of the past in the process of policy-making is one of the manifestations of memory as the "symbolic power." Memory as the "structural power" may be reflected in the agenda setting by political elites. The latter are those who decide how to frame, present, interpret,

\footnotetext{
${ }^{47}$ Müller, 25-26.

${ }^{48}$ Müller, 10.

49 The latter is especially the case if a nation/state had some past traumatic experience, such as a serious policy failure or foreign dominance.
} 
draw attention on, or on the contrary, avoid particular events or topics that are important from the point of view of a state, nation, society in general. Memory also determines events and persons that are "worth remembering" and that should be forgotten. It is a process of constructing meaning. As Martha Minow points out: "the alternation of forgetting and remembering itself etches the path of power.",50

Besides legitimacy, another important element that binds memory and political power, are historical analogies. The political elite usually reflect the dominant version of collective memory and build political discourse on historical analogies. Thus, memory is neither a vessel of truth nor just a mirror of interests. Definitely, policy-makers can use memory for their own benefits, however, they still have to rely on the historical past and the memory that shapes it. Politicians have power over memory, and memory also has power over them. ${ }^{51}$

Based on this theoretical framework, the further analysis will demonstrate how the Estonian political elite deal with the national memory in the process of policy- and decision-making. It will show both forms of manifestation of memory on the level of high politics - as a "structural" and "symbolic" power. The study will reveal interdependency of these two concepts and the influence one can assert on another.

\subsection{Methodology}

The empirical data for the analysis are speeches delivered by three high representatives of the Estonian political elite: the President, the Prime Minister, and the Minister of Foreign Affairs. All of them have a great influence on the domestic affairs and formation of the international image of the country. The President is the head of the state, the highest representative of the Republic in international affairs. Since Estonia is a parliamentary republic, the role of the president is rather symbolic; the actual political head of the state and government is the Prime Minister, who is responsible for decision-making,

\footnotetext{
${ }^{50}$ Martha Minow, Between Vengeance and Forgivenes: Facing History after Genocide and Mass Violence (Boston: Beacon Press, 1998), 199.

${ }^{51}$ Müller, 30.
} 
both in domestic and foreign politics. As European integration and membership in the EU has been one of the main foreign policy priorities of Estonia and the coordination of the EU-related issues passes through the Foreign Ministry of Foreign Affairs, the speeches delivered by its head, the Minister of Foreign Affairs, are also included into the study.

The timeframe for collecting of empirical data is a period from the year 1991 until 2011 (from the restoration of independence of Estonia on $20^{\text {th }}$ of August 1991 until present). During that time, there have been three Presidents: Lennart Meri (in office from October 1992 until October 2001), Arnold Rüütel (October 2001 - October 2006), and Toomas Hendrik Ilves (current President, in office since October 2006); eight prime ministers: Edgar Savisaar (in office from August 1991 until January 1992), Tiit Vähi (January 1992 - October 1992), Mart Laar (October 1992 - November 1994), Andres Tarand (November 1994 - April 1995), Tiit Vähi (April 1995 - March 1997), and Mart Siimann (March 1997 - March 1999), Mart Laar (March 1999 - January 2002), Siim Kallas (January 2002 - April 2003), Juhan Parts (April 2003 - April 2005), and Andrus Ansip (current Prime Minister, in office since April 2005); and eleven Ministers of Foreign Affairs: Lennart Meri (in office from April 1990 until March 1992), Jaan Manitski (April 1992 - October 1992), Trivimi Velliste (October 1992 - January 1994), Jüri Luik (January 1994 - April 1995), Riivo Sinijärv (April 1995 - November 1995), Siim Kallas (November 1995 - November 1996), Toomas Hendrik Ilves (November 1996 - October 1998), Raul Mälk (October 1998 - March 1999), Toomas Hendrik Ilves (March 1999 - January 2002), Kristiina Ojuland (January 2002 - February 2005), Rein Lang (February 2005 - April 2005), and Urmas Paet (current Minister of Foreign Affairs, in office since April 2005). ${ }^{52}$

The main purpose of the study is to trace development of the Estonia's discourse on European integration from the perspective of memory politics. The goal is to observe how

\footnotetext{
52 The number of Prime Ministers and the Ministers of Foreign Affairs reflects the amount of personalities that have been in office, not the total number of all governments during the period under examination. Thus, for example, Mart Laar and Andrus Ansip have served both three terms as Prime-ministers; Urmas Paet has also been holding office of the Minister of Foreign Affairs of Estonia for three times.
} 
the discourse has been constructed, operated and changed during the twenty years of independent statehood; what is the role of memory and traumatic legacies of the Soviet past and how they have been reflected in the current policy-making process.

The study is based on the assumption that the Estonian political elite use the Soviet past of Estonia for two separate purposes. On the one hand, they present the Soviet experience as an accelerator of European integration and "Europeaness" of the country aiming to break away from the Soviet past and replace it with European present. However, at the same time the Estonian politicians maintain the continuity of the Soviet past constantly bringing to mind the illegality of the Soviet occupation and demanding international recognition and condemnation of the communist crimes.

I use the method of deductive reasoning to collect the empirical data for the study. To begin with the analysis, first I look through a number of speeches to test the suitability of my assumption and get some general picture. Then I establish three main criteria, or keywords, for selection of speeches: Identity, Baltic and Communism. Those are the main operational concepts I build my analysis on. The goal is to observe how the reflection of these concepts in the political discourse has changed during the period 1991-2011.

The Identity-centered criterion is related to following questions to be examined in the speeches: Who we (Estonians) are? Where we belong to? Why should we be considered as Europeans? What are the main factors that facilitate it (economic success, historical ties, cultural similarity/connection)? One of the Identity sub-divisions is Other/Self criterion: I select the speeches where I find a contraposition of negative Other (The Soviet Union) against Positive Self (Estonia) or Positive Other (Europe, the EU, Finland, Sweden). The main research question and purpose here is to define why and how the Soviet time and practices were/are bad, whereas European is good for the people of Estonia?

The Baltic-centered criterion is aimed to trace the change of meaning of the concept of Baltic during the post-communist transition in Estonia and demonstrate appeared shifts from the Estonia's point of view. Next chapters of the study explain the relevance of this term for the discussion and further analysis.

The Communism-centered criterion reflects the attitude towards the 
Soviet/communist experience and its remembrance as an element of Estonia's political discourse. Also, it shows the ways how the Estonian political elite deal with the legacies of the Soviet past (including crimes of the regime) on the international level.

The main keywords I draw attention when I reading speeches are: Soviet, Communist/Communism, Totalitarian, Europe/European, European Union, Baltic, Nordic/Scandinavian. I observe how those concepts are presented with relation to each other; what aspects political actors usually avoid or, on the contrast, emphasize in their speeches; whether there is any indirect message behind the official rhetoric.

Besides this, I also have in mind six arguments, or operational concepts, introduced by Evald Mikkel and Geoffrey Pridham in their study examining the Referendums on EU Accession in Estonia and Latvia. ${ }^{53}$ The scholars identify them as "pro-EU accession arguments," which are National Sovereignty/Independence, Security, Economic, European Values/Standards, Historical, the Future. When doing my research I also mark how abovementioned concepts have been presented and framed in speeches by high political representatives.

The analytical part of the study is divided into four parts: de-Sovietization, "application," "negotiation," and "membership." This periodization is developed by combining the approaches of David J. Smith and Karen Henderson and accommodating them for Estonia's case. ${ }^{54}$

\footnotetext{
53 Evald Mikkel and Geoffrey Pridham, "Clinching the "Return to Europe": The Referendums on EU Accession in Estonia and Latvia," West European Politics 27 (2004).

${ }^{54}$ Smith examined post-communist transition in two stages: De-Sovietization (1991-1994) and Europeanization (1994-2002). Henderson, who also investigated the process of European integration of Central and Eastern European countries, divided the transition phase into two: the "application" and "negotiation" periods. The former started with the collapse of the Soviet Union and lasted until the beginning of the accession negotiations between the EU and former communist bloc republics. The second, the "negotiation" period followed the "application" period and lasted until the first wave of EU's eastern enlargement in 2004. Henderson did not include the third, "membership" phase in her periodization of European integration, just referring to "membership" as a distinct stage (David J.Smith,"The Devil and the Deep Blue Sea": European Integration, National Identity and Foreign Policy in Post-Communist Estonia" in Ideology and National Identity in Post-Communist Foreign Policies, ed. by Rick Fawn (London: Frank Cass, 2004), 164-171; Karen Henderson, "Exceptionalism or Convergence? Euroscepticism and Party Systems in Central and Eastern Europe," in Opposing Europe? The Comparative Party Politics of Euroscepticism. Volume 2, Comparative and Theoretical Perspectives, ed. by Aleks Szczerbiak and Paul A. Taggart (Oxford: Oxford University Press, 2008), 120-121).
} 
The study does not include speeches and statements by all political representatives mentioned above. The primary explanation for that are established criteria for the research. The analysis contains only those speeches, interviews, references, remarks and statements that match the criteria and are in focus of the study. Also, the time one or another political representative held an office matters too. Thus, for example Riivo Sinijärv had been the Minister of Foreign Affairs only for seven months, whereas Kristiina Ojuland - for almost three years, Toomas Hendrik Ilves - for five years, and Urmas Paet - for more than six years. The list of speeches also demonstrates that some elite representatives are cited more often than others, as for example, Lennart Meri, Toomas Hendrik Ilves, Mart Laar. One of the explanations to this is again a total duration of their time of service (Lennart Meri - ten years as a President of the Republic, Toomas Hendrik Ilves - five years as a Minister of Foreign Affairs and five years as a President, Mart Laar - five years as a Prime Minister). Another explanation is their activity on domestic and international level.

The theoretical framework developed in the current chapter creates a basis for further analysis. It explains the main principles of interaction between memory and political power and manifestations of memory in high politics. In order to proceed with the analytical part, I find it necessary to provide an overview of European collective memory and Estonian national memory and reveal some discrepancies existing between them. It facilitates understanding of the whole research idea as well as assumptions and findings of the analysis. For the same reason I include into the study a brief description of the main historical preconditions that have shaped the process post-communist transition and European integration of Estonia. 


\section{CHAPTER 2: ESTONIA'S MEMORY IN EUROPEAN MNEMONIC LANDSCAPE}

The current chapter is divided into three parts. The first part deals with the European collective memory and the main patterns of its formation with regards to the World War II remembrance. This part contains an explanation why memory is still dividing Europe into two parts as it used to be in the post-war period. Also, it describes the main events, principles and regimes the European collective memory is based on and shows how the Eastern enlargement of the EU has challenged the European memory space.

The second part provides overview of the Estonia's national memory and the key elements it is built on. This part involves examination of the process of formation of national history narrative, memory and identity of Estonians. It also explains how a conceptual pair Self/Other has influenced identity and memory construction.

Juxtaposition of the first and second parts of the chapter reveals the obvious divergence between European and Estonian collective memory and indicates the main causes for that. The third part demonstrates how this divergence and the particular moments of Estonia's past are reflected in the process of European integration of Estonia.

\subsubsection{Memory as a Dividing Line Between Western and Central - Eastern Europe}

The collective memory space of the European Union has been challenged by the last, fifth enlargement of the EU in 2004 and 2007, when a number of former postcommunist republics were accepted as members. World War II and the post-war period divided Europe into two rival camps: capitalist Western Europe and communist Eastern Europe. The end of the War brought victory to former, and occupation to latter. A different level of economic and socio-political development was not the only dividing line between the Western and Eastern European states. The psychological gap reflected in divergence of their history and memory narratives appeared to be even more challengeable. The process of European integration moderated some of the economic, political and judicial differences between the new and old members. However, institutional and bureaucratic requirements of the EU could not overturn their psychological perceptions. Memory still distinguishes 
Western Europeans from their Eastern counterparts.

Undoubtedly, World War II was one of the most significant events in European history. Dan Diner referred to the war as to the foundational event in a Uniting Europe ${ }^{55}$ In fact, it was. First of all, World War II united people and nation-states in terms of enormous losses and destruction it brought. Second, the post-war period reconciled and united the former enemies and led to the formation of one of the most important international organizations, the European Coal and Steel Community, a predecessor of the European Union, in 1951.

However, that unity and reconciliation did not apply to the whole Europe, but only to its Western part. For Central and Eastern Europe, the war did not end in 1945 with the defeat of the main "evil" of Europe - Adolf Hitler. Central and Eastern Europeans fell under the communist regime of another ideological tyrant, Joseph Stalin, and existed under the foreign dominance until the collapse of the Soviet Union in 1991. Even now, when 65 years have already passed after the end of the war, some of the legacies of that period still continue to assert their influence. In particular, it applies to the politics of memory, ongoing debates on restitution, truth reconciliation and war remembrance in Europe. As Diner points out, "World War II never ended." ${ }^{, 56}$ Richard N. Lebow supports this argument, referring to the politics of memory in postwar Europe and arguing that it has an obvious starting point 1945, some crucial turning points - 1968, 1979, 1991, but no endpoint. ${ }^{57}$ If fact, some of the war-related issues still remain unresolved. Recognition and condemnation of the communist crimes, committed during and after World War II in the former Soviet republics is one of them.

\footnotetext{
${ }^{55}$ Dan Diner, "Memory and Restitution: World War II as a Foundational Event in a Uniting Europe" in Restitution and Memory: Material Restoration in Europe, ed. by Dan Diner and Gotthard Wunberg (Berghahn Books, 2007), 9.

${ }^{56}$ Diner, 1.

${ }^{57}$ Richard N. Lebow, "The Memory of Politics in Postwar Europe" in The Politics of Memory in Postwar Europe, edited by Richard N. Lebow, Wulf Kansteiner, and Claudio Fogu (Duke University Press, 2006), 36.
} 


\subsubsection{The Patchwork of European Memories}

Maria Mälksoo, Konrad H. Jarausch and Thomas Lindenberger distinguish four major communities in the European memory landscape with regards to the World War II remembrance: an Atlantic-Western European (former Western military opponents of Germany), German-speaking West-Central Europe, East-Central Europe, and the Eastern European states of the Russian Federation. The patterns of their remembrance are very different: D-Day of 1944 and the Allied Victory in Europe on $8^{\text {th }}$ of May 1945 in case of Atlantic-Western European community; deep traumas resulting from the experience of two dictatorships, bombing raids and total defeat in case of German-speaking West-Central Europe; experience of two occupations (Nazi and Soviet) and subsequent existence under the Soviet control in case of Central and Eastern European countries; and the victory in "The Great Patriotic War" in Russian case. ${ }^{58}$

The third category, the East-Central European memory community is the focus of this study. Within this group, there are also some sub-divisions. The Baltic States, Croatia and Slovakia have a clear anti-Soviet consensus. States such as Poland, Hungary, the Czech Republic, Ukraine and Slovenia are characterized by the open conflicts and controversial reworking of the past. Ambivalence or apathy toward the communist past can be found in Serbia, Macedonia and Albania. ${ }^{59}$ In Bulgaria and Romania, continuity with the Soviet period has been preserved to some extent, whereas in Belarus and Moldavia the memory of the socialist period is still a source of identity-building. ${ }^{60}$

\footnotetext{
${ }^{58}$ Konrad H. Jarausch and Thomas Lindenberger, "Contours of a Critical History of Contemporary Europe: a Transnational Agenda," in Conflicted Memories: Europeanizing Contemporary histories, ed. by Konrad H. Jarausch and Thomas Lindenberger (Berghahn Books, 2007), 4; see also Maria Mälksoo, "The Memory Politics of Becoming European: The East European Subalterns and the Collective Memory of Europe," European Journal of International Relations 15 (2009): 654; Maria Mälksoo, The Politics of Becoming European: a Study of Polish and Baltic Post-Cold War Security Imaginaries (London: Routledge, 2010), 90.

${ }^{59}$ Claus Leggewie, "A Tour of the Battleground: The Seven Circles of Pan-European Memory," Social Research 75 (2008): 221.

${ }^{60}$ Kirsti Jõesalu, "The Meaning of "Late Socialism": Analyzing Estonians' Post-Communist Memory Culture," Asia Europe Journal 8 (2010): 296.
} 


\subsubsection{Determinants of the European Collective Memory}

The Holocaust is often referred as the main element of the European collective memory. Identification with Europe is presented as "a refutation of a Europe occupied, exploited, and oppressed by a murderous Nazi regime in a disastrous war accompanied by unfathomable war crimes, and a Europe ravished by genocide and a Holocaust perpetrated by Nazi Germany." formation of the Holocaust-centered approach. One such regime - "a common European currency" - emerged immediately after the end of the war; the main foundation for it was the consensus on Germany's sole guilt for the atrocities of the World War II and the Holocaust. ${ }^{62}$ Another memory discourse was the historical myth of national resistance and victim status of all formerly occupied countries. Both discourses were dominant until 1970s in Western Europe. Afterwards, there was a shift from a "history of the victors" to a "history of the victims"; the period of the Holocaust as a "common unifying memory" started. The Holocaust was presented as an act of barbarism, against which European unity has to be strengthened. ${ }^{63}$ Over the course of the past thirty years this memory discourse transformed and was universalized, reaching far beyond the paradigm of Jewish experience of catastrophe. Pierre Nora described this situation as "whoever says memory, says Shoah." ${ }^{64}$

The Holocaust theme has been institutionalized, cultivated, regarded whether as an "arch-event" or the "negative core event of the $20^{\text {th }}$ century." 65 Legacies of crimes committed under Nazism and Fascism during World War II were systematically approached

${ }^{61}$ Hartmut Kaelble, "Identification with Europe and Politization of the EU since the 1980s" in European Identity, ed. by Jeffrey T. Checkel and Peter J. Katzenstein (Cambridge: Cambridge University Press, 2009), 200.

${ }^{62}$ Tony Judt, "The Past is Another Country: Myth and Memory in Post-War Europe" in Memory and Power in Post-War Europe: Studies in the Presence of the Past, ed. by Jan-Werner Müller (Cambridge: Cambridge University Press, 2002), 161.

${ }^{63}$ Eva-Clarita Onken, "The Baltic States and Moscow's 9 May Commemoration: Analysing Memory Politics in Europe," Europe Asia Studies 59 (2007): 30.

${ }^{64}$ Müller, 14.

${ }^{65}$ Diner, 2, 11-19. 
and analyzed. ${ }^{66}$ The establishment of the Task Force for International cooperation on Holocaust Education by the EU developed common curriculum on Holocaust studies. ${ }^{67}$ Despite the fact that majority of the European countries have adopted and agreed on the institutionalization of the Holocaust Remembering (construction of specific museums and monuments, establishment of a specific Holocaust Memorial Day etc.), this issue in general still causes a lot of disputes.

\subsubsection{Eastern Enlargement of the EU and European Collective Memory}

The fall of the Iron Curtain, the collapse of the Soviet Union and the EU eastern enlargement in 2004/2007 brought a number of competing memory regimes into the European collective memory space. One of them is based on the argument equalizing barbarism and cruelty of the Nazi crimes with the atrocities committed by the Soviets during and after World War II. ${ }^{68}$ Emergence of this memory regime is explained by the uneven attention given to these two oppressors. First, in the contrast to Nazism, the communist regimes in the former Soviet bloc and their traumatic repercussions for contemporary politics have not received comparable academic examination. ${ }^{69}$ The memories and legacies of communism are still controversial in the European historiography, and even today they have hardly been accommodated within the "Western" public consciousness. ${ }^{70}$ Whilst there was established clear legal and philosophical bases for condemnation of the Nazi crimes, the criminal prosecution of communist offenders was mostly an individual prerogative of the former states-victims (post-communist republics) themselves. $^{71}$

Europe is still divided in terms of political, moral, and legal evaluation of the Soviet

\footnotetext{
${ }^{66}$ Henry Rousso, "History of Memory, Policies of the Past: What For?" in Conflicted Memories: Europeanizing Contemporary Histories, ed. by Konrad H. Jarausch and Thomas Lindenberger (Berghahn Books, 2007), 29.

${ }^{67}$ Rousso, 33.

${ }^{68}$ Onken, 2007, 30.

${ }^{69}$ Maria Mälksoo, "The Discourse of Communist Crimes in the European Memory Politics of World War II," Ideology and Discourse Analysis Conference: Rethinking Political Frontiers and Democracy in a New World Order (Denmark: Roskilde University, 2008): 1.

${ }^{70}$ Rousso, 24.

${ }^{71}$ Mälksoo, 2008, 3.
} 
heritage. In the light of all these arguments, the claims of Diner that the Holocaust pretends to become the foundational event for European collective memory and World War II - the foundational event in a Uniting Europe, remains highly questionable. ${ }^{72}$ How could we refer to these two concepts as foundational events, if their interpretation and remembrance is so divergent across European countries? How could the War be a foundational event if it led to the foreign occupation of a half of the European countries?

One of the factors that explains existing asymmetry in Western reflection and investigation of the communist crimes is the "Iron Curtain" that divided East and West. Add to this a powerful Soviet propaganda machine and extremely little knowledge of Western Europeans about the real situation in occupied Eastern Europe. Evans points out, that Western historians were too compliant to the Soviet propaganda; they could not realize the full scale of the communist crimes. The myths and misunderstanding created by the communist propaganda had a profound influence on their interpretation of the history of Central and Eastern European states. The Western public was too attached to the existing scenario of World War II and the subsequent success of European integration to consider its rethinking. Western Europeans wished to "draw a line" under the legacy of World War II, and their experience with the Nazi Germany and Hitler by the Nuremberg trial. ${ }^{73}$ When the process of European unification started, they put great emphasis on cooperation and integration, rather than on digging up the past. At the same time, the construction of the socialist society was progressing in the Eastern bloc. Therefore, European borders, identities and also memories were frozen by East/West division and the "desire, common to both sides, to forget the recent past and forge a new continent.",74

Furthermore, as the Western European countries actually never fought against the Soviet Union and the Red Army, Stalin could never compete in the popular mind with Hitler as the "evil enemy.", Mälksoo adds one more supposition causing inequality in the

\footnotetext{
72 Diner, 9-19.

${ }^{73}$ Rousso, 29; Mälksoo, 2008, 5.

74 Judt, 157.

75 Martin Evans, "Memories, Monuments, Histories: The Re-thinking of the Second World War since 1989," National Identities 8 (2006): 331.
} 
remembering and research of the Nazi and the Soviet regimes' criminal records - there has never been a Soviet Nuremberg trial; therefore, documentation of the crimes of Nazism is much broader and well-known in comparison to the communists'." 76 Also, Russia, the Soviets' successor state, is interested in the Soviet heroization, maintaining an image of World War II as the Great Patriotic War and the Red Army as a liberator of oppressed countries of Central and Eastern Europe. Therefore, any attempts to clarify this part of history are usually met with counter-defense from Russia's side.

The next part of the chapter gives overview to the formation of Estonia's national memory, history and identity. It defines the main aspects that shape Estonians' memory and marks down the key agents that have influenced national memory and identity construction - Negative and Positive external Others of Estonia.

\subsubsection{Formation of Estonia's National Memory and History Narrative}

The pre-World War II history of Estonia can be symbolically divided into three stages: "ancient freedom," "700-year night of slavery" and "independence."77 The period of "ancient freedom" ended in the thirteenth century when the territory of Estonia was conquered, first, by Danes and Germans, then by Swedes, and at last, by Russians. The Estonian Liberation War (or the War of Independence) 1918-1920 and the birth of Estonian Republic on 24 February 1918 terminated the seven centuries long era of foreign oppression. An interesting paradox - though the War was fought against the Bolshevik Red Army, the prominent moment was the battle against the German Landeswehr near Võnnu in the summer 1919 that Estonians won. During the pre-war period, Germans were perceived as negative significant Other for Estonians, "conquerors and exploiters of the Estonian peasantry."78 Vahur Made goes even further, presenting the whole "700-year night of

\footnotetext{
${ }^{76}$ Mälksoo, 2008, 3.

77 Tamm, 505.

${ }^{78}$ Veronika Kalmus, "Is Interethnic Integration Possible in Estonia?: Ethno-Political Discourse of Two Ethnic Groups," Discourse \& Society 14 (2003): 672.
} 
slavery" as equal to the Baltic Germans' dominance in Estonia. ${ }^{79}$ It explains the significance of the battle near Võnnu for Estonians. Final victory gained after successive phases of losing and gaining liberty became a powerful symbol of freedom and independence, and also a central element of Estonia's national memory and history narrative. ${ }^{80}$ The narrative presents a short period of independence as a success story of the Estonian nation and its only natural form of existence. ${ }^{81}$

Estonia became an independent state after World War I, in 1918 and preserved this status during the interwar period. World War II put an end to the twenty years long period of its independent statehood. According to the Molotov - Ribbentrop Pact and its secret protocols concluded between Stalin and Hitler, Estonia was incorporated into the Soviet Union in 1940. The next year the country was invaded by Nazi Germany and then again recaptured by the Red Army and forcibly reincorporated into the Union of Soviet Socialist Republics in 1944. The Estonia's national narrative presents Soviet occupation as an era of aberration, "discontinuity," "an abnormal state of affairs," the age of repressions and exploitation of Estonians. ${ }^{82}$ The Soviet period has an important role in the identity formation of Estonian people and the state itself. Kirsti Jõesalu divides the Soviet time into two main phases: High Totalitarianism/Stalinism and Normalization/Post-Stalinism. ${ }^{83}$ In memory studies, the former is related to the experience of cultural trauma (in that period, two main deportations of 1941 and 1949, and also mass arrests and repressions took place). Attitude towards the latter is more ambivalent.

\footnotetext{
${ }^{79}$ However, this perception changed in the beginning of World War II, when Germans left Estonia. Since that time, previously resented Germans, the negative Other transformed into positive Other. More explanation - in the next subsections.

80 Tamm, 505.

${ }^{81}$ Pääbo, Potential of Collective Memory Based International Identity Conflicts, 87.

${ }^{82}$ Evald Mikkel and Andres Kasekamp, "Emerging Party-Based Euroscepticism in Estonia," in Opposing Europe? The Comparative Party Politics of Euroscepticism. Volume 1, Case Studies and Country Surveys, ed. by Aleks Szczerbiak and Paul A. Taggart (Oxford: Oxford University Press, 2008), 296; see also Jõesalu, 296; Marko Lehti, Matti Jutila and Markku Jokisipilä, "Never-Ending Second World War: Public Performances of National Dignity and the Drama of the Bronze Soldier" in Contested and Shared Places of Memory, ed. by Marko Lehti and Jörg Hackmann (London: Routledge, 2010), 28; Pääbo, Potential of Collective Memory Based International Identity Conflicts, 87.

83 Jõesalu, 294.
} 


\subsubsection{Russia (the Soviet Union) as a Significant Negative Other for Estonia}

Russia has always been a significant Other for Estonia. However, if during the late nineteenth and early twentieth centuries Estonians' perception of their large eastern neighbour was neither positive nor negative ${ }^{84}$, since the 1940s onwards widespread opposition to Soviet regime has placed Russians as the most significant negative Other for Estonia. ${ }^{85}$ As Petersoo claims, "negative othering of Russia is almost inevitable" after fifty years of Soviet domination; it is and will further assert influence of Estonia's foreign policy towards Russia. ${ }^{86}$ Made adds that relations between the two countries remain "dogged by controversies over politics, culture, security, history and mentality," although there is seemingly some "softening" of tensions nowadays. ${ }^{87}$ Petersoo distinguishes between Russians' external and internal otherness in case of Estonia. The former is about Russia as a state; the latter refers to the Russian-speaking minority living in Estonia. A great number of Russian Estonians are/were World War II immigrants and their descendants. Internal othering of Russians was especially widespread in the immediate period after the restoration of Estonia's independence. As Petersoo claims, the Russian-speaking minority "functioned as the internal negative Others against whom Estonians asserted their nationness." 88

The Soviet past had various meanings in public and private. ${ }^{89}$ For the most part, it is explained by the existence of two parallel history narratives in Estonia - the official Soviet one and unofficial national. The former was a sort of artificial creation for Estonians; externally imposed by the communist authorities and widely dispersed in public sphere, it aimed to construct the Soviet Estonian identity and replace Estonian national narrative by the Soviet one. However, Estonian national narrative remained untouched in the collective memory of Estonians; it was maintained and transmitted through the families (the private

\footnotetext{
${ }^{84}$ That time, the Estonian national elite presented Estonia as a guardian of the East (Russia) against the West (mainly Germany). (Heiko Pääbo, "Estonian Transformation. From an Eastern Outpost in the West to a Western Outpost in the East" in Cultural Transformations After Communism Central and Eastern Europe in Focus, ed. by Krzysztof Stala and Barbara Tornquist-Plewa (Lund: Nordic Academic Press, 2011), 253).

${ }^{85}$ Petersoo, 122.

${ }^{86}$ Petersoo, 122.

${ }^{87}$ Made 187, 190.

${ }^{88}$ Petersoo, 124. More information about the Russian-speaking minority - in the next chapter.

${ }^{89}$ Jõesalu, 294.
} 
sphere). Pääbo claims that unofficial history counternarrative enabled Estonians to restore their independent national memory. ${ }^{90}$ Tamm supports that argument. Referring to the late 1980s and early 1990s, he argues that "an active reconstruction of pre-war historical memory took place" in parallel with the restoration of an independent statehood of Estonia. ${ }^{91}$ As Jõesalu adds, together with the reconstruction of pre-war historical memory, Estonian memory work was focused also on the traumatic events of the 1940s-1950s. ${ }^{92}$ Experiences of that severe period were involved in the formation of the dominant narrative in Estonian society in the beginning of 1990s. For the great part, the narrative of that transitional post-communist stage was build on the principle of legal continuity with the pre-war republic and was aimed on the establishment of that continuity and international recognition of newly independent Estonia. The brief period of independence 1918-1940 had not only high symbolic significance; also, it enabled Estonian political elite to regard the country as a restored state, not a successor state of the USSR.

\subsubsection{Europe as a Significant Positive Other for Estonia}

Similarly to the role of negative Other, the positive Other's influence on the identity and memory formation of a nation is considerable as well. The positive Other usually performs as a source of admiration, as a model or standard towards which the nation aspires. The most significant positive Other for Estonia has always been Finland. During the age on national awakening ${ }^{93}$, the architects of Estonian nationalism had been "primarily oriented towards Finland," regarding the latter as an example to follow. ${ }^{94}$ There are a number of factors explaining closeness of two countries. The most important is their

\footnotetext{
${ }^{90}$ Pääbo, Estonian Transformation, 1.

91 Tamm, 505.

92 Jõesalu, 294.

93 The era of national awakening of Estonians (Ärkamisaeg) began in the mid nineteenth century and ended with the declaration of the Republic of Estonia in 1918. At that time, Estonians acknowledged themselves as a nation deserving the right to self-government and started to build up their own independent nation and national society.

${ }^{94}$ Helmut Piirimäe, "Historical Heritage: the Relations Between Estonia and Her Nordic Neighbors" in Return to the Western world: Cultural and Political Perspectives on the Estonian PostCommunist Transition, ed. by Karl Erik Rosengren, Marju Lauristin, and Peeter Vihalemm (Tartu: Tartu University Press, 1997), 63.
} 
linguistic and cultural proximity. Estonian and Finnish belong to the same group of FinnoUgric languages; Estonia and Finland have a number of common traditions and national holidays; the Estonian national epic Kalevipoeg is based on a plot of the Finnish epic Kalevala. ${ }^{95}$ Marju Lauristin argued that in the Soviet time, the Finnish significant Other helped Estonia to "maintain an inner distance from the Soviet-Russian, i.e., Byzantine forms of everyday practices during the five decades of occupation." 96 Besides that, Estonia and Finland are also close geographically - the distance between the Estonian capital Tallinn and the Finnish capital Helsinki is 85 kilometers (53 miles) by sea.

Europe has been a significant external Other for Estonia for many centuries already. Despite the fact that relations between Estonia and Europe started to develop through establishment of foreign rule on Estonian territory by Danes, Germans and Swedes (since thirteenth until eighteenth century), in Estonian collective memory those times have good associations. Stories of a mythical "Good Old Swedish Time," that are still widespread in Estonian society, are a good confirmation to it. According to Petersoo, Swedish cultural heritage is regarded as a constituent part of Estonian identity till nowadays. ${ }^{97}$ Though Germans initially had a status of the negative Other for Estonians, in twentieth century this perception changed in the opposite direction. When the Baltic Germans left Estonia in the beginning of World War II and were not regarded anymore as a threat to the Estonian nation and Estonian culture, their image was reconsidered and became positive. Estonia could not underestimate the contributions the Baltic German nobility made to the nation, such as development of agriculture and education as well as introduction of the Lutheran Protestantism which played an important role in further development of a written Estonian language. ${ }^{98}$ Today, Germans are one of the positive external Others for Estonia; German inheritance is valorized in the society.

\footnotetext{
${ }^{95}$ Together with Basque and Hungarian, Estonian and Finnish are the only non-Indo-European languages spoken in Europe.

${ }^{96}$ Lauristin, 35.

97 Petersoo, 127.

${ }^{98}$ Vahur Made, "Estonia and Europe: a Common Identity or an Identity Crisis?" In Post-Cold War Identity Politics: Northern and Baltic Experiences, ed. by Marko Lehti and David. J. Smith (London: Frank Cass, 2003), 184-185.
} 
Thus, the long history of foreign rule actually contributed to development of "Europeaness" of Estonia. Estonians have emphasized their belonging to Europe and the Western cultural space by various traditions and practices the former oppressor brought to them, such the "legal and educational systems, developed through the centuries according to Swedish and German traditions." 99 In addition, Estonia took part in the shaping of European civilization - being actively involved in the Protestant Reformation, and later in the process of nation-building. In the nineteenth - twentieth century, there was an attempt to conceptualize Estonian culture as part of European culture made by a neo-romantic literary movement "Young Estonia" (Noor Eesti). The main slogan of the group stated: "More culture! More European culture! Let us remain Estonians, but let us become Europeans too. We want to discover the ideas and forms towards which we are impelled by our national spirit, character, and needs on the one hand, and by European culture on the other." 100 Taking into consideration abovementioned factors, it becomes clear why Estonia feels to be a genuine part of European culture and civilization, seeing Europe as its "natural home." 101

However, since the Enlightenment, there has been a tendency in Western Europe to regard Estonia as "Europe but not quite Europe." "102 Two centuries of subordination to the Russian Empire (1721-1918) as well as recent history of the Soviet rule (1944-1991) played an important role in the distortion of Estonia's "European" image. Since the 1980s Estonia attempted to restore the lost during the years of the Soviet domination ties with its positive Other - Europe. This course of rapprochement with Europe and the Western World has been widely known under the name of "Returning to Europe." ${ }^{103}$ In the subsequent

\footnotetext{
${ }^{99}$ Marju Lauristin, "Contexts of transition" in Return to the Western world: Cultural and Political Perspectives on the Estonian Post-Communist Transition, ed. by Karl Erik Rosengren, Marju Lauristin, and Peeter Vihalemm (Tartu: Tartu University Press, 1997), 35.

${ }^{100}$ W.K. Matthews, "The Background and Poetry of Gustav Suits. A Study in Estonian Symbolism, " American Slavic and East European Review 9 (1950): 118.

${ }^{101}$ Steven Stoltenberg, "Latvia, Lithuania, and Estonia: Determined Euro-Atlantists" in The European Union and the Member States, ed. by Eleanor E. Zeff and Ellen B. Pirro ([S.1.]: Lynne, 2006), 412.

${ }^{102}$ Mälksoo, 2009, 655.

${ }^{103}$ The terms "Return to Europe" or "Back to Europe" first appeared as slogans of dissidents and intellectuals of some of the former Soviet republics appealing to the bloodless liberation of Eastern part of Europe from
} 
years, the "Return to Europe" narrative became central to Estonian political and cultural discourse. According to Lauristin, Estonia's desire to be "accepted again by the West and to be recognised as an integral part of the Western cultural realms" was even stronger motivator for Estonians than "mere economic or political motivation could ever be.",104

The next part of the chapter explains the meaning of the term "Returning to Europe" as well as describes its significance for Estonia. In this part, I demonstrate how European aspirations of Estonia and the historical legacies of its Soviet past are interconnected. Also, I show the positive and negative sides of Soviet experience on post-communist transitional period in Estonia.

\subsubsection{Estonia's “Returning to Europe"}

For Estonia, the Soviet era represented "false history" and a state of abnormality. ${ }^{105}$ The period of existence under the Soviet regime and association of Estonia with its Soviet past also after the restoration of independence (expressed in widespread international labeling of Estonia as a post-Soviet Republic) distorted the perception of Estonia as a European country, as a part of a "true" Europe. Thus, the "Return to Europe" symbolized a transformation of Estonia from "false" into "normal", "full," "genuine” European state. 106

The meaning of the concept "Return to Europe" has been changing during the whole period of post-communist transition. In the beginning stages, Estonia used it as a legitimating force and an appeal towards international community to recognize its independence. The discourse "Return to Europe" provided an opportunity to restore

the rule of the Communist oppressor. Later on, the concept "Return to Europe" became a prominent element of the official political agenda of these countries.

${ }^{104}$ Lauristin, 29.

${ }^{105}$ Lehti, 2006, 71.

${ }^{106}$ Maria Mälksoo, "The Memory Politics of Becoming European: The East European Subalterns and the Collective Memory of Europe," European Journal of International Relations 15 (2009): 656; see also Basak Z. Alpan, "Intellectual and Political "Europe": Rupture or Continuity in Central Europe," in Central European History and the European Union: the Meaning of Europe, ed. by Stanislav J. Kirschbaum (Basingstoke [England]: Palgrave Macmillan, 2007), 154. 
damaged economic and diplomatic relations with the West. The Estonian political elite used the term also as a tool of domestic and foreign politics. The slogan "Return to Europe" was used as a counter measure against previously dominant communist parties in national election campaigns that were held right after restoration of independence. Europe was a symbol of peace, capitalist (market) economy and democracy - concepts which did not evoke associations with the Soviet regime. The concept "Return to Europe" was very symbolic; it indicated willingness of Estonia towards democratic values and standards, associated with Europe and pre-Soviet history of the country. In later phases of postcommunist transition, the term performed as a driving force to join the European Union.

\subsection{2 "Return to Europe” or From "One Union to Another Union"?}

However, the memories of the Soviet period were too fresh and painful yet. In Estonia, as well as in other former communist bloc republics, a possibility of joining the EU was perceived with alert. Potential membership was regarded as a continuation of the Soviet period, as a perspective of going from "one union to another union" and fulfilling the commands from Moscow before and from Brussels now. ${ }^{107}$ Quite often, critics of the European integration created parallels between the EU and the Soviet Union, insisting on obvious similarities between those two: the bureaucratic nature, the necessity to subordinate part of the national autonomy to the supranational body, ineffective economic systems. Dissatisfaction with the economic system of the EU was expressed in statements like "going from the free market to central planning" or "from socialism to socialism." In the case of Estonia and the Czech Republic these arguments were especially meaningful. After the collapse of the Soviet Union, these states rapidly and successfully transformed their socialist economic systems into free market economies. Restrictions that would follow membership in the EU were perceived as a danger to effective functioning of the new economic systems. $^{108}$

The main fear, though, was related to the loss of national identity. For countries that

\footnotetext{
${ }^{107}$ Mikkel and Kasekamp, 296.

${ }^{108}$ Membership in the EU is accompanied with a number of regulations that are imposed on every candidate country to adjust its domestic system with the EU norms.
} 
just restored their independence, it was difficult to surrender a part of their freedom again. For Estonia and two other Baltic States, Latvia and Lithuania, this question was of particular importance. In contrast to other communist-dominated countries from Central and Eastern Europe which were members of the Warsaw Treaty and formally preserved their independence with relative autonomy in the decision-making process, three Baltic States were officially incorporated into the Soviet Union and fully subordinated to unionwide established rules and norms. This factor has a strong effect on mentality, moral perception of external dominance and attitude towards national identity also after the dissolution of the Soviet Union. Psychologically, it was more difficult for the Baltic States to devote a part of their recently regained sovereignty to the EU. ${ }^{109}$

\subsubsection{Historical Legacies and Memory Framing Estonia's "Return to Europe"}

Membership in the EU required adjustment of domestic legislation with the EU's standards. One of the most disputed and negotiated areas in case of Estonia were laws related to preservation of national identity of the republic - citizenship and language legislation. One of the legacies of the Soviet period that distinguishes Estonia (and Latvia) from other former communist republics is a large Russian minority. According to recent data, Estonia consists of 68.7 per cent of Estonians and 25.6 per cent of Russians. ${ }^{110}$ This demographic composition is a consequence of Soviet-style industrialization, russification (under the guise of "sovietization") and resettlement policies of the Soviet Union. ${ }^{111}$ The main goal of these policies was establishment of the Russian dominance in non-Russian communities and amalgamation of citizens of all Soviet Union republics in order to create a unique Soviet nation and identity. As a result, the number of ethnic Estonians in the country decreased by one third during the forty-six years of the Soviet regime. If by the end of World War II more than 90 per cent of population was ethnic Estonian, then by the end

\footnotetext{
${ }^{109}$ Mikkel and Kasekamp, 296.

${ }^{110} \mathrm{https} / / / \mathrm{www}$. cia.gov/library/publications/the-world-factbook/geos/en.html.

${ }^{111}$ Russification is an imposition of the Russian language and some other cultural attributes to the nonRussian communities. The most affected spheres of russification are culture, education and politics. Russification includes introduction of native Russians into societal and power structures of targeted nations/countries with simultaneous eradication of native non-Russian from these structures.
} 
of the Soviet rule the proportion was 61.5 per cent of Estonians against 38.5 per cent of representatives of other nationalities (mostly Russians, but also Ukrainians, Belarusians and natives of other Soviet republics). Soviet efforts directed on reducing the number of Estonians to minority in their homeland as well as relegation of their language and culture to a "second-class status" had a long-lasting psychological impact on Estonians. After the restoration of independence the question of preserving national identity together with other attributes of the statehood (citizenship, language, culture, traditions) was very important and vulnerable issue for Estonians. In 1992, Estonia adopted a Law on Citizenship that made a process of obtaining Estonian citizenship very demanding for non-Estonian inhabitants. Automatic citizenship was granted only to people who were citizens of the prewar Estonia, and their descendants. Estonia justified such decision by the principle of legal continuity with the First Republic. According to the international observers' position, Estonian citizenship law corresponded to international standards and did not violate any norms. ${ }^{112}$ However, Russian authorities accused Estonia in adopting discriminatory laws that violated the human rights of the non-Estonian population. The EU and OSCE also expressed criticism, and pressured Estonia to adapt less restrictive legislation and to accommodate the Russian-speaking minority in the country. Such reaction of the international community to Russia's claims made Estonia suspicious of the West and intensified its fears of losing national identity within the EU. ${ }^{113}$

A popular perception of Estonia as a (post)-Soviet country is another inheritance of the Soviet past that played an important role in Estonia's European debate. Even nowadays it is still common to hear about Estonia as a former Soviet country or a post-communist country, despite the fact that Estonia is a member of the EU. A number of factors contributed to this image: the fifty years-long communist past, relatively unknown preSoviet history, the short period of independence, the small size (45 $228 \mathrm{sq} \mathrm{km}$ ) and a geographic location of the country. The last factor is important for two reasons. Estonia's location on the periphery of Europe combined with its proximity and a direct border with

\footnotetext{
112 Stoltenberg, 224.

${ }^{113}$ Mikkel and Kasekamp, 297.
} 
the Russian Federation could explain why Estonia is sometimes mistakenly considered to be a part of Russia. A large ethnic minority (both Russian-speaking citizens and noncitizens) supplements this misleading image. All these factors taken together explain Estonia's attempts to protect its statehood. Quite often, Estonia is accused because of its nationalist tendencies, of national chauvinism. In fact, the Estonian political elite used nationalism as a protection from external influences, especially in the immediate time after restoring independence. During the post-communist transition, appeals to preserve national identity have been always in the heart of Estonia domestic and foreign policy discourse. The EU's membership provided a new framework for them.

Regional identity is an additional factor that has played role in the Estonia's discourse on European integration. Estonia is often referred as a "Baltic country". Despite the wide usage and seeming unambiguity of that term, in fact it is rather problematic from the historical perspective.

The Baltic in a broad sense means that a country has an access to the Baltic Sea. There are nine states that surround the Baltic Sea and share a common coastline (Estonia, Latvia, Lithuania, Finland, Sweden, Denmark, Germany, Poland and Russia). However, the term Baltic is more known as a collective name for three countries - Estonia, Latvia, Lithuania. The concept was developed after the World War I when these states first gained their independence (1918) and emerged from the ruins of the Russian Empire. ${ }^{114}$ The first references to Estonia, Latvia and Lithuania as Baltic belong to the Russian Czar Alexander III who gave the countries a status of the Baltic provinces (Прибалтийские губернии) and included them into the Baltic region (Прибалтийский край).

After World War I the term Baltic used to be the main identification of the regional identity of Estonia, Latvia and Lithuania. It has both negative and positive connotations. With relation to two powerful neighbours of the Baltic States - Russia and Germany - the term reflected the smallness and marginality of the Baltic countries as opposite to the

${ }^{114}$ Lehti, 2006, 70 . 
strengths and significance of their big neighbours. ${ }^{115}$ Also, the concept Baltic is sometimes associated with the process of easternization. ${ }^{116}$ In the Soviet times, the term "Baltic" distinguished three republics from the Soviet Union on the basis of their exceptionality: relatively high living standard, good economic indicators, willingness to be different and preserve national identity. Not without reason other Soviet nations later regarded Estonia as the "Soviet West;" 117 the Estonian SSR together with two other republics of the Soviet Pribaltika ${ }^{118}$ were seen as a Westernized enclave within the Soviet Union, that in addition, had privileged access to an "electronic window to the West" - the Finnish television broadcasts. ${ }^{119}$ Thus, in the Soviet period, the term Baltic has definitely positive meaning for the Balts themselves.

However, for the West the Baltic meant nothing until the late 1980s; Estonians, Latvians and Lithuanians became known during the "Singing Revolution," a sequence of events that led to independence of three Baltic States in August 1991. Mass demonstrations and protests in different forms showed efforts and desire of people for freedom. Estonians became famous for singing patriotic national songs forbidden by the Soviet regime. Another manifestation of discontent was the Baltic Way - a peaceful demonstration that marked the fiftieth anniversary of the Molotov-Ribbentrop Pact, by which Hitler and Stalin divided Europe into the spheres of influence. ${ }^{120}$ The Baltic Way was a very powerful and symbolic statement against the Soviet regime. It was a joint effort of three Baltic States that showed their common wish, unity, solidarity and a real aspiration for freedom.

Several years after the restoration of independence, the term Baltic lost its initial meaning in Estonia. By the late 1990s, it was rarely used in public, and was even taken to

\footnotetext{
${ }^{115}$ Lehti, 2006, 70.

${ }^{116}$ Lehti, 2006, 69.

${ }^{117}$ Eiki Berg, "Local Resistance, National Identity and Global Swings in Post-Soviet Estonia," Europe-Asia Studies 54 (2002): 115.

${ }^{118}$ Pribaltika means "at the Baltics" in Russian.

${ }^{119}$ D. Smith, 161.

120 The Baltic Way or the Baltic Chain was a human chain consisting of two million people - a peaceful demonstration that occurred on 23 August 1989. The Baltic Way was over 600 kilometres and crossed the three Baltic states - Estonian SSR, Latvian SSR, and Lithuanian SSR, three republics of the former Soviet Union.
} 
represent something shameful. ${ }^{121}$ The ties between the Baltic States became looser. Estonia reoriented itself towards the Scandinavian (Nordic) countries, Sweden and Finland. The Estonian political elite always emphasized strong ties with those countries, claiming that "Estonia maintains its Nordic characteristics as its inheritance" and stressing Estonian people psychological attachment and Nordic mentality: "we Estonians have always felt that

we belong to the Nordic world." 122 Partly, attempts to place Estonia closer to Scandinavian countries was a natural move - Finland and Sweden have always been the biggest trade partners of Estonia and economic cooperation with these countries in fact only intensified with time. On the other hand, such drastic reorientation was a deliberate effort of the Estonian political elite to detach Estonia from the Baltic region and attach it to the Nordic. Another obvious case demonstrating Estonia's attempt to distance itself from the Baltic States appeared in the negotiation process to join the EU. The next chapter provides detailed overview and explanation to this phenomenon.

The current chapter demonstrated the divergence of Estonia's national memory in the context of European collective memory. The main cause for that is the recent history of existence under the communist rule that distinguish Estonia from its Western-European counterparts. The chapter showed the influence the Soviet experience asserted on the process of European integration of Estonia. Information presented in this chapter provides a necessary context for better understanding of the main research idea of the study and allows to proceed with the analysis.

\footnotetext{
${ }^{121}$ Lehti, 2006, 71.

${ }^{122}$ Lehti, 2006, 72.
} 


\section{CHAPTER 3: REFLECTION OF MEMORY IN POLITICS}

In the current chapter I demonstrate how the Estonian political elite has built and framed the discourse of European integration in Estonia during the different stages of postcommunist transition. The chapter reveals the link that exists between memory and politics. Based on theoretical assumptions discussed in the previous chapters, the analysis of the speeches delivered by the leading political representatives of Estonia shows how memory may perform as a "symbolic" and "structural" power. Also, the chapter demonstrates how the legacies of the past are intertwined with the present and which role the past experiences might play in shaping the political discourse of a country. Especially, in case of Central and Eastern Europe, "where the past is ever present.",123

The transitional period is divided into four stages: "de-Sovietization," "application," "negotiation" and "membership." The first stage, "De-Sovietization", started on $20^{\text {th }}$ of August 1991 (restoration of Estonia's independence) and lasted until $31^{\text {st }}$ August 1994 (withdrawal of the Russian troops from Estonia's territory). Second period, "application”, followed "De-Sovietization" and finished on $1^{\text {st }}$ of February 1998 (when the association agreement to accede the EU entered into force). Third stage, "negotiation" continued until $1^{\text {st }}$ of May 2004 (when Estonia joined the EU). Last one, "membership" is currently ongoing.

\section{Stage I: De-Sovietization}

The era of de-Sovietization started when Estonia restored its independence on $20^{\text {th }}$ of August 1991. The state was especially vulnerable during this period. Estonia was afraid of the Russian Federation, a successor state of the Soviet Union, and its potential attempts to encroach upon freshly regained freedom. The President of the Republic, Lennart Meri, warned the Estonian people and the international community against "new, aggressive

${ }^{123}$ Kirschbaum, x. 
conception of foreign policy [of the Russian Federation], oriented to neo-colonialism." 124 Referring to one Russian journal, Meri claimed that Russia had adopted an active postimperialist policy, and Estonia and Latvia would be its first victims. These fears were intensified by the presence of the Russian troops on Estonian soil. A statement that "security [is] to be our foreign policy Priority Number One" defined that period. ${ }^{125}$

The majority of the political speeches delivered during the de-Sovietization period were directed towards achieving faster international recognition of Estonia's independence and protection from a potential counter reaction of the former oppressor. The main strategy Estonia used to present itself was victimization. Constantly stressing the illegality of the Soviet occupation, unwillingness of the Russian Federation to negotiate in the questions of common borders and troops withdrawal, the inability of Estonia to influence the situation because of its small size, Estonia tried to draw international attention and receive protection and support for the endangered country, one of "the smallest states of Europe." ${ }^{26}$ Estonia was constantly sending messages to the Western world to influence Russia to withdraw its troops from its territory as fast as possible. By those appeals Estonia stressed the necessity of international resolution of the situation, and also emphasized its vulnerability vis-à-vis Russia: "of course, this [troop withdrawal] can only take place with the support of the international community." 127

Another source of worries was Russia's emerging concept of the "Near Abroad.", 28 Estonia preferred to see itself as the "near abroad" of the European Union and all its members states, not of Moscow. ${ }^{129}$ Appealing to the democratic principles as the foundation of Western countries, and their "willing obligation" to stand by these principles, Estonia

\footnotetext{
${ }^{124}$ Lennart Meri, Speech at The Inaugural Conference Of The Baltic Institute For Strategic And International Studies. Tallinn [Estonia]: 16 December 1993.

${ }^{125}$ Indrek Tarand, Partnership for Peace and Confidence Building in Europe. Helsinki [Finland]: 4 May 1994.

${ }^{126}$ Meri, Tallinn, 16 December 1993.

${ }^{127}$ Tarand, Helsinki, 4 May 1994.

${ }^{128}$ The „Near Abroad“ or Ближнее Зарубежье in Russian. The term “The Near Abroad” emerged in 1992 as a collective term for the former Soviet Republics. From the Russia"s perspective, the "Near Abroad" region was still its sphere of its influence; the Russian Federation considered itself as a leader of that area who had to provide a stability on its periphery.

${ }^{129}$ Trivimi Velliste, Speech at the NUPI-CSIS Conference on Baltic and Nordic Security. Oslo [Norway]: 21 September 1993.
} 
attempted to secure support and protection of Western world.

Already in the late 1980s the Baltic States were associated with emerging democratic traditions and programs. In the early 1990s, this tendency was intensified. The president's speeches abounded in statements like "the first democratic elections held in Estonia since the second World War," "Estonia is a state ruled by law", "the first democratically-elected constitutional government in Estonia since World War Two." 130 First, it was an appeal to show a legal continuity with the First Republic 1918-1940 that was unlawfully annexed by the Soviet Union. Second, such statements were made in order to contrast democratic aspirations of Estonia to the undemocratic former Soviet Union (at that time, already synonymous with the Russian Federation). Estonia was on a way of constructing and reaffirming its new identity; focusing of own positive Self, Estonia emphasized the negative "otherness" of the Soviet Union even more and tried to distance from the Soviet past as fast as possible. The political elite always emphasized Estonia's willingness to become a state with a functioning democracy as opposed to the former communist rule. Constantly claiming that Estonia was a state ruled by law that respects democracy and human rights, politicians highlighted Estonia's Western and European credentials. Also, Estonia tried to represent itself as a medium that had brought the forbidden ideas of democracy and the parliamentary tradition from Europe to the Soviet Union. Drawing parallels between own small size and enormous harm to "the colonial state" that Estonia, "eyesore to the empire-minded Russia", had caused, the political elite accentuated the contribution of Estonia in infecting the Russian state apparatus. The president strengthened his arguments by using metaphors, comparing the influence of democratic ideas and practices on Russia with plague "dreaded in the middle ages. ${ }^{131}$

During the first decade after restoring independence, the references to the legal continuity of the First Republic served as a prerequisite of Estonia's demands for international protection and recognition. The principle of legal continuity was a dominant element in Estonia's de-Sovietization discourse. Introduction to the speeches featured

\footnotetext{
${ }^{130}$ Lennart Meri, Speech at the Reception for the Members of the Finnish Foreign Ministry and the Corps Diplomatique. Helsinki [Finland]: 9 October 1992.

${ }^{131}$ Meri, Tallinn, 16 December 1993.
} 
concepts like "the War of Liberation" and "the Peace Treaty of Tartu" provided legitimacy to the arguments. ${ }^{132}$ The principle of "legal continuity" was presented as a bridge over the Soviet times to the interwar republic; this connection was supposed to turn everything in between into something illegal and foreign. ${ }^{133}$

One of the most obvious signs and attempts to break with the past and distance Estonia from its long Russian/Soviet experience was the radical shift of cadres in the government. Prime Minister Mart Laar (1992-1994) "cleaned the house" by replacing the old Soviet administration with a new generation, young people in their twenties and thirties, who "were not spoiled by the soviet past." 134 It was an attempt to change the infamous Soviet system characterized by nepotism and political manipulations. Such rapid overturn of cadres demonstrated the willingness of Estonia to break away with the Soviet past by adopting new practices and get rid of the Soviet mentality directing behaviour of former elites. ${ }^{135}$

The best way to break away with the communist identity was to replace it with a new one. Though appeals to national identity as a cornerstone of Estonia's statehood were especially sound and frequent that time, Estonia was clearly aware of necessity to ensure some additional source of identity, whether European, or Western, or Nordic. During the de-Sovietization phase, Europe or the European Union were not seen as a single and definite goal, a primary aim. Estonia's main intention was rather to show its "nonbelonging" to the former Soviet Union through attachment to whatever international organization or communities. It was a way to "overcome the burdens of the past", "the decades of darkness." 136 The regional Baltic identity was also emphasized and positively valued. First, the Baltic identity represented the image of common interests, unity and stability that the Balts had showed recently in their collective attempts to liberate from the

\footnotetext{
${ }^{132}$ Treaty of Tartu was a peace treaty signed between Estonia and Russia (the Russian Soviet Federative Socialist Republic) on $2^{\text {nd }}$ February 1920 ending the Estonian War of Independence. According to the document, Russia recognized the independence of Estonia which had previously been a part of Imperial Russia. The treaty also resolved border and property disputes between two countries. Treaty of Tartu has a strong symbolic meaning in Estonia's collective memory.

${ }^{133}$ Lehti, 2006, 71.

${ }^{134}$ Mart Laar, Transition and the Consolidation of Democracy. The Case of Central Europe (1990 - 2000). Budapest [Hungary]: 1 November 2000.

${ }^{135}$ Stoltenberg, 413; Mikkel and Kasekamp, 298.

136 "Decades of darkness" or fifty years of the Soviet rule (Meri, Helsinki, 9 October 1992).
} 
Soviet rule. Access to the Baltic Sea allowed Estonians to relate themselves not only with other countries surrounding it, but also with all of Europe through that connection. The region Estonia belonged to was promoted as having "an exciting potential to become the next dynamic growth zone of an integrating Europe, in the new Europe of regions." 137

Security considerations that have always been and will remain in the core of Estonia's political discourse were first steps towards the emergence and clarification of the EU discourse. Formation of the collective European identity in Estonia's case started with the creation of "a new European Defence Identity." 138 It presented an opportunity to become integrated into the "New" Europe, as opposed to the "False" Europe - Estonia's existence under the Soviet regime. Europe was a symbol of the future, of freedom, of hope, of a better life. The Estonian people's future was a "free Europe, a part and member of which we [Estonians] had been for the past eight centuries."139 The emphasis on Estonia's historical ties with Europe has always been an element of political discourse in the postcommunist transitional period.

The era of de-Sovietization lasted until the final withdrawal of remaining Russian troops from Estonia's soil on $31^{\text {st }}$ August 1994. During this period, Estonia's political discourse was dominated by security fears and search for protection from every possible source. Therefore, the debate was not so much European, but rather international; more a "return to the Western World" than "return to Europe". It had nothing to do with the EU as such. The main goal at that time was to get an access to the main international organizations: the North Atlantic Treaty Organization (NATO), United Nations (UN), Council of Europe, the Organization for Security and Co-operation in Europe (OSCE), and the European Union just as one element of that list. Membership in those organizations was seen as a confirmation of Estonia's "European-ness" and an appeal to recognize the illegality of the Soviet occupation as an "artificial" imposition, violation of Estonian national identity, culture, and traditions. ${ }^{140}$ The primary Estonia's strategy was to present

\footnotetext{
${ }^{137}$ Meri, Helsinki, 9 October 1992.

${ }^{138}$ Luik, Luxembourg: 9 May 1994.

${ }^{139}$ Lennart Meri, New Year's Address to the Estonian People. Tallinn [Estonia]: 31 December 1992.

${ }^{140}$ Stoltenberg, 412.
} 
itself as a victim of the communist regime and to prove that the country had a full right to be a member of Western community. The discourse of "returning to Europe" was based on the master narrative of the Estonian nation and the principle of legal continuity with the First Republic. Estonia used the discourse "return to Europe" as a primary tool to protect and distance itself from the Russian Federation and marginalize the burden of the Soviet past, and also as an appeal to revive the country from the fifty years-long period of international isolation and strengthen its place in the "true" Europe. ${ }^{141}$ During the period of de-Sovietization, Estonia tried to rebuild its identity and present itself as an antipode to the negative Russian (Soviet) Other and in the light of Positive European (Western) Other.

\section{Stage II: Application}

The "application" stage refers to the period of time between submitting an official request to become a member of the EU (24 ${ }^{\text {th }}$ of November 1995) and entering into force of the Europe Agreement ( $1^{\text {st }}$ of February 1998). ${ }^{142}$ The Europe Agreement, along with the Free trade agreement, created an umbrella for Estonia's preparations for the EU's membership. ${ }^{143}$ They established a framework for EU - Estonian relations providing a basis for regular discussions on specific issues, high-level meetings of senior officials, and implementing the pre-accession assistance. ${ }^{144}$ In order to adapt the periodization of the post-communist transition to the particular Estonia's case, I will shift the beginning of the “application" period from November 1995 to August 1994. It will help to avoid gaps in the analysis. August 1994, or to be precise, $31^{\text {st }}$ of August 1994 was an important date for Estonia, since that day indicated the final withdrawal of the Russian troops from its territory and indicated the beginning of a new period.

$31^{\text {st }}$ of August 1994 was one of the turning points in Estonia's history and foreign policy. It gave a clearer outline for Estonia's discourse on European integration as well.

\footnotetext{
${ }^{141}$ D. Smith, 165; Mikkel and Kasekamp, 298.

142 The Europe Agreement, or the association agreement to accede the EU between the European Communities and its member states and the Republic of Estonia.

${ }^{143}$ The Free trade agreement was concluded on 18th of July 1994 and entered into force on 1st of January 1995.

${ }^{144}$ http://ec.europa.eu/enlargement/archives/enlargement_process/past_enlargements/eu10/estonia_en.htm.
} 
Another important factor was the accession of Finland and Sweden into the EU on $1^{\text {st }}$ of January 1995. ${ }^{145}$ It was no coincidence that Estonia applied for the EU membership later that year. ${ }^{146}$ The third reason that caused more active and definite position with regards to the EU membership was a statement by Estonia's foreign minister, Toomas Hendrik Ilves, who recognized that Estonia probably would not be included into the first round of NATO enlargement. Ilves' prediction encouraged Estonia to focus on obtaining EU membership. ${ }^{147}$ The security threat was still dominant element of Estonia foreign policy consideration. If there would not be "hard" security that NATO could provide, Estonia definitely needed some kind of security, and EU's "soft" security option seemed to be the best alternative.

In general, there was an obvious shift in rhetoric of the Estonian political elite right after the $31^{\text {st }}$ of August 1994. Estonia did not stress so much its status of victim as it was during the stage of de-Sovietization. There was much more confidence, clarity, and determination. Estonia still perceived a security threat from the side of its eastern neighbour. However, instead of mere appeals to international community for protection, there were developed different frameworks for managing security options. Two weeks after the withdrawal of the Russian troops, Jüri Luik, the Minister of Foreign Affairs of Estonia, came up with the main principles of Estonia's foreign policy and presented them as a mathematical equation: Security $=$ Normalization + Integration. ${ }^{148}$ Normalization referred to the Estonia's relations with the Russian Federation, integration - with trans-Atlantic community, and security united all elements of the equation. The president of the Republic, Lennart Meri presented the same approach, but from the different perspective. He resorted to geometry, and defined security space of Estonia as a "Strategic Quadrangle," that consisted of lines drawn between and among Tallinn, Brussels, Washington and Moscow. ${ }^{149}$ The keywords of that approach were the same as in case with Luik's equation: security,

\footnotetext{
${ }^{145}$ Finland and Sweden are Estonia's closest neighbours and the main trade partners.

146 Mikkel and Kasekamp, 299.

${ }^{147}$ Mikkel and Kasekamp, 299.

148 Jüri Luik, Quo Vadis, Estonian Foreign Policy? Roosta [Estonia]: 11-12 September 1994.

${ }^{149}$ Lennart Meri, Address at the 1995 Plenary Meeting of the Trilateral Commission. Copenhagen [Denmark]: 22 April 1995.
} 
normalization and integration. Again, security was the primary element; security depended largely on the actions of all actors of the "Strategic Quadrangle."

In general, the "application" period was characterized by increased enthusiasm towards the Russian Federation: "Right now, both we and Russia enjoy an historic opportunity to improve relations." There was even a special approach towards Russia called a policy of Positive Engagement, whose key (operative) word was "mutual": mutual respect for sovereignty, mutual respect for national security interests, mutual refraining from verbal and other confrontations, mutual respect for international norms of behaviour, most importantly, in the area of human rights." 150 Introducing those ideas, Estonia still relied on the principle of legal continuity: the main element behind the policy of Positive Engagement was the Tartu Treaty. Estonia appealed to the common duty of Estonia and Russia to "make that peace again." In the beginning, Estonia saw the Treaty as the only valid basis for a border agreement. However, in the context of the policy of "pacification with the East," Estonia declared its readiness to soften insistence on Tartu Treaty as the only option. According to Toomas Hendrik Ilves, the minister of foreign affairs of Estonia, such a decision was "not merely necessary for the demarcation of Estonia, (but) also the first step showing that Estonia is a responsible nation with a European-like behaviour." 151 By this statement, Ilves not only reflected willingness of Estonia to overcome a very important element of the Soviet legacy. Stress on the European-like behaviour reaffirmed the new positive European identity of Estonia in the light of negative Russian Other, presented as a rigid, incompliant, uncooperative, undemocratic state.

Another manifestation of reorientation to Europe was expressed in the rapid change of trade partners. According to Meri, in 1991, the whole industry of Estonia (95 percent) was conducted with "what is now called the former soviet union or FSU", whereas in four years after restoring independence, the proportion changed considerably - 65 per cent of trade was now with Western European countries. Pointing out that for the most part, these Western European countries were Finland and Sweden, the president emphasized the historical and cultural ties between Estonia, Finland and Sweden, referring to these states as

\footnotetext{
${ }^{150}$ Luik, Roosta, 11-12 September 1994.

${ }^{151}$ Toomas Hendrik Ilves, "Eesti poliitika Euroopastumine," Luup No 6 (1997), available also online http://luup.postimees.ee/luup/97/06/sise2.htm (accessed 26.04.2011).
} 
“the Former Swedish Empire, or FSE." "152 Meri gave positive value to Estonia's existence under the Swedish occupation, and presented it as a good experience. This experience changed the mentality of Estonians, and as a result, was one of the main factors that determined Estonia's success as an independent state: "Our culture heritage is one of a West-finnic substrate overlayed with a strong vineer of Germanic and Swedish Lutheranism. It is finnic individualism tempered by 800 years of the German legal system. It is finnic stubbornness transformed by the same Swedish tradition of hard, dogged work... In a word, one reason we are successful is that we are Scandinavians." ${ }^{153}$ Immediately after the remarks that admired Swedish occupation, the president moved to the "cruel truth" of the Soviet experience. Such immediate contraposition of positive external Other Sweden against negative external Other Soviet Union, the association of Swedish rule with success and the Soviet one with the loss of freedom, strengthened the negative image of the Soviet experience even more.

An interesting tendency, in the light of communist experience the former negative Other Germany was transformed into positive Other. From the nineteenth century (the era of "national awakening") and until the post-war Soviet occupation, the rule of the Baltic Germans was mostly referred as a period of darkness, a synonym for the colonial oppression and enslavement of the indigenous "Estonian" peasantry. ${ }^{154}$ Now the period of "700-year night of slavery" was seen through the lens of legal heritage: "Estonia has been part of the Roman-Germanic legal system for over 700 years... This legal basis is a nursery where everything else springs up; it is the prerequisite, the basis and the very guarantor of the survival, the development and the success of our modern state... When we think why perestroika took such a direction, and was not a tragic collapse or a civil war - the legal system has shaped also the Estonian way of thinking." 155 Now the Soviet Union took over the evil image of colonial state; some statements by the president of Estonia, Lennart Meri,

\footnotetext{
${ }^{152}$ The Former Swedish Empire existed between 1611 and 1718, and it was a period of Estonia's subjugation to the Swedish rule (Lennart Meri, Address at a Fundraising Dinner for the Baltic Studies Center. Seattle, Washington [United States]: 31 October 1995).

${ }^{153}$ Meri, Seattle, 31 October 1995.

${ }^{154}$ Marko Lehti, A Baltic League as a Construct of the New Europe (Frankfurt: Peter Lang, 1999), 63.

${ }^{155}$ Lennart Meri, Address at the Carnegie Endowment for International Peace. Washington, D.C. [United States]: 19 October 1995.
} 
were clear confirmations of it. ${ }^{156}$ The Soviet Union, and its current successor, the Russian Federation, replaced Germany as a dominant negative Other in Estonia's master narrative, national consciousness and identity construction. ${ }^{157}$

Besides a tendency to present the Soviet time as an era of aberration, and appeal through it to the necessity of recognition of Estonia as a part of Europe, the political elite often presented the Soviet past as a symbol of strength, as an experience that made Estonian people more mature, realistic, wiser, stronger. Estonia has experienced life under communism - nothing could be worst. In this context, Estonia's smallness turned into its strength, it was a prerequisite of unity. A small nation with a huge desire for freedom and readiness to unite and fight to the last: "Estonia's strength is our common sense, our aptitude for learning and our will to act. That Estonia is exactly where it is. That it is just as large as it is. Estonia's small size can be an asset. Even our underwater diving record - fifty years in the murky depths of Soviet occupation, arriving ashore gasping for breath, with liberty, equality and fraternity still clenched between our teeth - is an asset." 158 On this stage, Estonia felt itself more confident than during the de-Sovietization period; the Soviet experience gave this country and its nation such a lesson that Estonia felt itself obliged not only to talk about its historical experience in order "to avoid its recurrence in the rest of Europe," 159 but also to "teach Europe" which, unlike Estonia, have been living in illusions during the Cold War era. ${ }^{160}$

In general, during the term in office of the President Meri, Estonia's dominant strategy in the phase of "application" might be called as "The Little Country That Could." ${ }^{161}$ By that, the president meant the success of Estonia in rapid implementation and

\footnotetext{
${ }^{156}$ In some of his speeches, President Meri referred to the Russian Federation as to (neo)colonial state, to the era of Russian colonial supremacy, to the decades of darkness (Meri, Tallinn, 31 December 1992; Meri, Tallinn, 16 December 1993).

${ }^{157}$ D. Smith, 160.

${ }^{158}$ Lennart Meri, Speech at the 78th Independence Day Celebrations. Tallinn [Estonia]: 24 February 1996.

${ }^{159}$ Lennart Meri, Remarks at the Jagellonia University of Krakow. Krakow [Poland]: 30 April 1998.

${ }^{160}$ Meri, Tallinn, 16 December 1993.

${ }^{161}$ Meri, Washington, D.C., 19 October 1995. Also, there is a book with the same title "Estonia: Little Country That Could" written by Mart Laar and published in 2002.
} 
functioning of political and economic reforms in the country that had liberated itself from the rule of foreign oppressor just four years ago. In this period, the self-praising of Estonia by its political elite was common. In order to prove its qualification for membership in the EU, Estonia's politicians constantly quoted different sources that marked Estonia's success: "our economic reform program hailed by the IMF and the World Bank as among the most successful in Central Europe. It is no wonder that some observers refer to Estonia as a modern Wirtschaftswunder." 162 The decision of the EU to begin accession negotiations with Estonia only reinforced and confirmed its own belief that it is a "Little Country That Could": could make a rapid transition from the Soviet system towards free market economy and democracy, could achieve the best indicators among the former Soviet bloc countries, could become a member of the EU too. This feeling was supported by the fact that Estonia was the only post-Soviet state (among officially incorporated into the USSR republics) that was accepted to begin negotiations to join the EU. The two other Baltic States, Latvia and Lithuania, were not. ${ }^{163}$ At that time, Estonia's tendency to distance itself from two other Baltic States became especially evident. The only "Balt" accepted for negotiations, Estonia wanted to show its individuality, exceptionality, successfulness. ${ }^{164}$ It was proud of itself and accepted major responsibility at the same time: a tiny and relatively unknown country located on the periphery of Europe that was accepted to be a candidate of the first wave of eastern enlargement. Estonia had to prove its worthiness and eligibility to be placed in the same line with Central and Eastern European states, not burdened by the status of a former Soviet Union republic. Estonia's Baltic identity did not seem to be a benefit any more. It undermined its new international image, and represented continuity with the Soviet past. In light of this, Estonia's attempts to marginalize its Baltic regional identity and its "separatist" tendencies looked quite justified. Estonia wished the Baltic States to be regarded individually, not as three interconnected countries as it was used in the Soviet and early post-Soviet period. An Estonian foreign minister, Toomas Hendrik Ilves, portrayed

\footnotetext{
${ }^{162}$ Meri, Washington, D.C., 19 October 1995.

${ }^{163}$ In July 1997 the European Commission acknowledged Estonia together with four Central and Eastern European countries (the Czech Republic, Hungary, Poland and Slovenia) as being ready for EU membership within five years, whereas Latvia and Lithuania were postponed .

${ }^{164}$ Estonia's formal EU accession negotiations started in March 1998, Latvia's and Lithuania's were opened only two years later, in February 2000.
} 
the tendency to consider the Baltic States as a single entity as "poorly fitting, externally imposed category" and called into question such phenomenon as the Baltic identity, claiming that there was nothing uniting three "very different" countries, "with completely different affinities" in the Baltic area: neither common culture nor language group or religious tradition. ${ }^{165}$ Eroding ties between Estonia, Latvia and Lithuania and denying Estonia's belonging to the group of three Baltic States, Ilves attempted to marginalize Estonia's Soviet past and deliberately distance the country from other Balts. Estonian political elite wanted to demonstrate that Estonia was different, not like other former Soviet Union republics most commonly characterized as backward and underdeveloped. The last phases of the "application" period identified a change of the dominant narrative directing the "return to Europe" discourse: the old foundational narrative of the independent First Republic has been gradually replaced by the new "success story" that praised economic and democratic developments of post-communist transitional stage. ${ }^{166}$

\section{Stage III: Negotiation}

The beginning of this stage was marked by the entering into force of the Europe Agreement ( $1^{\text {st }}$ of February 1998) and the subsequent opening of the membership negotiations in March of the same year. The conditional end of the phase was the completion of the accession negotiations between the EU and Estonia at the Copenhagen Summit in December 2002. However, it would be wrong to consider the period of negotiation finished by the closing of all the chapters of the acquis communautaire. In this study, the negotiation stage is prolonged until Estonia's entering into the EU in May 2004. During this period, a number of important events happened: the Treaty of Accession was signed on $16^{\text {th }}$ of April 2003 and the Estonian European Union membership referendum

\footnotetext{
165 "I think it is time to do away with poorly fitting, externally imposed categories. It is time that we recognize that we are dealing with three very different countries in the Baltic area, with completely different affinities" (Toomas Hendrik Ilves, Estonia as a Nordic country. Stockholm [Sweden]: 14 December 1999).

${ }^{166}$ Lehti, 2006, 83.
} 
was held on $14^{\text {th }}$ September $2003 .^{167}$

Estonia's main strategy in the negotiations with the EU was to present itself and maintain an image of "the best student in the class", or, using the official EU's terminology, to implement the acquis communautaire ${ }^{168}$ in full by the date of accession. ${ }^{169}$ Among the fifth wave candidates, Estonia had always had an image of the most eager country to join the EU. Estonia tried to be the best and quickest in "doing its homework". Estonian political elite understood that in order to become a member of the EU, great efforts should be made. As the Estonian Prime Minister Mart Laar explained: "Brussels is not Moscow, we could not resort to the gift of the gab or any tricks. We needed to work hard." ${ }^{170}$ By that statement, Mr. Laar presented the nature of the Soviet Union - unpredictable, unfair, tricky - as a total opposite to the demanding, but fair European Union. Also, he emphasized Estonia's willingness to become a part of the democratic world. However, such parallels between the EU and the Soviet Union might in fact be quite risky; confrontation of the center in Moscow and Brussels portrays latter as democratic, though still hegemonic authority. The Foreign minister Toomas Hendrik Ilves also used a method of drawing parallels between the European Union and the Soviet Union to emphasize the benefits and positive role of the former and discredit even more the latter. Defending certain EU practices that in the media were often called "the stupidities associated with EU policy," Ilves made an immediate reference to the Soviet Union; comparing those two, he argued that for successful functioning of the genuine Union of sovereign nations [the EU] a compromise was needed. Thus, the minister encouraged Estonian people as well as other candidate states to be tolerant towards certain policies, standards, norms or requirements

\footnotetext{
${ }^{167}$ The Estonian European Union membership referendum was intended to show Estonia's public opinion whether Estonia should join the EU or not. 66,83 \% of electorate expressed their support towards EU's membership, whereas one third (33,17\%) were against (source: http://www.vvk.ee/varasemad/?v=rh03). ${ }^{168}$ Acquis communautaire represents the cumulative body of European Community (EC) laws, objectives, substantive rules, policies and, in particular, the primary and secondary legislation and case law - all of which form part of the legal order of the European Union (EU). This includes all the treaties, regulations and directives passed by the European institutions, as well as judgements laid down by the European Court of Justice. The acquis is dynamic, constantly developing as the Community evolves, and fundamental. All Member States are bound to comply with the acquis communautaire.

${ }^{169}$ Mikkel and Kasekamp, 301.

${ }^{170}$ Mart Laar, Preparations for accession of Estonia to the European Union. Tallinn [Estonia]: 18 January 2001.
} 
imposed by the EU that sometimes might be not preferred or even disliked by one country, but are necessary for other member states. ${ }^{171}$ Also, Ilves regarded the acceptance of Estonia to begin negotiations with the EU as a clear indicator that the state "genuinely ceased to be a "former Soviet republic.",172

In order to distance Estonia from its Soviet past and its symbols, the Estonian political elite took a more persistent course directed on rapprochement with the Nordic countries, the "true" Europeans. As it has already been mentioned before, Estonia was not positive anymore about its belonging to the family of the Balts and tried to separate itself from them. Among the Estonian political elite, Ilves was especially skeptical about such phenomena as a common Baltic identity. He argued that Estonia, Latvia and Lithuania just did not have it. The only element that tied three countries together was their common negative, "unhappy", "imposed from the outside" Soviet experience: occupations, deportations, annexation, sovietization, collectivization, russification. ${ }^{173}$ According to Ilves, psychologically and culturally Estonia belonged to so called Yule-land, together with Finland, Sweden, Norway, Denmark, Iceland, and the British Islands. The minister stressed that Estonia has much more in common with this group of countries than with Latvia and Lithuania. Referring to the term Yule-land, Ilves indicated the similarities among the countries that share this cultural entity. As an example, Ilves demonstrated how the word Christmas is expressed in national languages of the countries belonging to the Yule-land and showed the difference with two other Baltic States and Russia. The word Christmas means Jõul in Estonian, Joulu in Finland, Jul in Sweden, Norway, Denmark, Jol in Iceland, Yule on the British Isles. In contrast to Yule-land countries, Latvians call Christmas Ziemastvetki, Lithuanians - Kaledos, and Russians - Рождество [Rozhdestvo].

Among other factors that demonstrate Estonia's belonging to the Yule-land, are particular cultural and mental characteristics, such as stubbornness, rationality, pragmatism,

\footnotetext{
171 "This will become clear only when negotiations have reached an end. Now, all chapters remain open - on both sides. I think the term "EU stupidies" is a journalistic cliché. Some things may not be to our liking, but they are to someone else's. For a genuine Union of sovereign nations - unlike the Union of Soviet Socialist Republics - to function requires compromises to meet everyone's interests" (Toomas Hendrik Ilves, Interview to City Papers. Tallinn [Estonia]: 27 November 1999).

${ }^{172}$ Ilves, Tallinn, 27 November 1999.

${ }^{173}$ Ilves, Stockholm, 14 December 1999.
} 
tendency to work hard. Also, Yulelanders have similar levels of development in the area of Information and Communication Technologies - they are the best in the world in Internet connections and in mobile phone penetration. Furthermore, Yule-land countries have the lowest levels of corruption worldwide. According to Ilves, Estonia, often regarded as a backward former "Soviet Republic," outperformed in these areas not only other former communist countries, but also leading European powers, such as Germany and the United Kingdom for example. ${ }^{174}$ Ilves also noticed that Estonians were the only ones who were able to break down the initial prejudices of the EU toward the "former soviets" and presented the popular image of Estonians as the "new Finns."

In a broader perspective, there has always been a moment of competitiveness with others in the Estonia's "return to Europe" discourse. Emphasizing its achievements and eligibility for starting negotiations to join the EU, the Estonian political elite constantly demonstrated that its country was able to surpass not only its closest neighbours, the former Soviet Republics, but also other states of the former communist bloc. Among the potential members from the fifth wave Cyprus and Malta were two countries without Soviet inheritance. Presenting Estonia's success as comparable only with Cyprus', politicians tried to marginalize Estonia's communist past and present its level of development as very close to a candidate state unburdened by the Soviets and thus more "Western:" "Estonia has made rapid progress. With 16 chapters closed in negotiations, we have lost only to Cyprus that exceeded us by just one chapter. Estonia has been able to increasingly assert itself."175

Some of the Estonian political figures stressed the exceptionality of Estonia even more, resorting to some strange comparisons. Thus, for example, the Prime Minister Mart Laar came up with such an argument: "Estonia is the only country among her counterparts where the recollection of a 2-rouble sausage does not conceive nostalgia for the warm shelter of a rotten empire. Estonians are the most optimistic people about their future in the

\footnotetext{
174 "Suprisingly given its backwardness as a "Soviet Republic" only eight years ago, Estonia ranks eleventh in the entire Europe [...] we are by far the highest ranked former Communist country and are more interneted than half the EU," "this same reassertion of Yulelander identity in Estonia in other measure is high-tech identity, mobile-phone use, where it is ahead of even Germany and quickly catching up to the world leaders, the Scandinavians," "[...] Estonia is 15th, a post-communist country but rated less corrupt than three members of the EU" (Ilves, Stockholm, 14 December 1999).

${ }^{175}$ Laar, Tallinn, 18 January 2001.
} 
entire Europe." ${ }^{176}$

Appeal to the Estonian people in the context of European integration had a special place and was of particular importance in case of Estonia. As in any democratic society, the wish of people had to be taken into account when the country was on the edge of some important changes. The Estonian people had to make a final decision whether Estonia would join the EU or not. For that purpose, a referendum on joining the EU had to be carried out in all candidate countries. The aim of the referendum was to clarify the level of public support for the integration. Among all countries from the fifth wave of Eastern enlargement, Estonia's case has been unique in terms of discrepancy of the political elite and public opinion towards the joining of the EU. In a country, reported and presented to be one of the most willful and diligent candidates to enter the EU, the level of public support has always been one of the lowest. For example, according to the Eurobarometer report that was made in March-May 2003 (some months before the referendum on $14^{\text {th }}$ of September 2003), at least every sixth Estonian citizen considered EU membership as a bad thing and in general Estonians were described as "almost as unfriendly towards the Union as the notoriously frosty Brits." ${ }^{177}$ Therefore, the EU issue and the coming referendum in particular was a great challenge for the Estonian political elite in many ways. First, they had to convince Estonians of the positive influence and benefits that membership would bring. Second, they had to do it in a way that would not leave an image that the choice of Estonians was manipulated or prescribed by the ruling elite. In that case, it would put into question the level of democratic development of Estonia and also create associations with the Soviet time when everything was decided for people by small political elite. Resorting to different rhetorical methods, Estonian politicians tried to present the European choice of people as their independent position. Stressing Estonia's achievements made in the period of post-communist transition, politicians placed them in the context of European integration and emphasized the role of ordinary people in that process: "Estonia's success is not attributable to any political party or fraction, but to the people of Estonia," "It is not politicians or government officers that accede to the European Union, but the State and

\footnotetext{
${ }^{176}$ Laar, Tallinn, 18 January 2001.

${ }^{177}$ The British people have always been the biggest EU critics (EUROBAROMETER EB59 - CC-EB 2003.2.).
} 
people of Estonia," "All citizens of Estonia, from countrymen to businesswomen will be citizens of the European Union." 178 The president of the Republic, Arnold Rüutel, portrayed a possibility to decide whether Estonia will become a Member State of the EU as a unique chance that history had given to the Estonian people to choose their destiny. In Rüütel's speech, a "Yes" vote was associated with stability and access to the richest common market, whereas a "No" vote - with the critical changes in Estonian domestic and foreign policy. Complementing his arguments by description of all benefits and support that the EU already gave and would give to Estonia in case of "Yes" vote, the president presented the EU as a vital element in solving the problems left to Estonians by the years of occupation. ${ }^{179}$ To counter widespread fears that membership in the EU might partly deprive the Estonian nation of its sovereignty and threaten its culture and national identity, Rüütel reassured Estonians that the EU would help to preserve and strengthen their national culture. Also, he claimed that membership would provide Estonia with an opportunity to express its opinion on matters significant for Europe matters and also share Europe's joys. All those things are especially significant for the Estonian people since they "have experienced the lack of it in the past."180

Encouraging people by the success stories of Finland and Sweden, the advantages the membership brought to them and assuring people of the safety of joining the EU by using an example of those countries, politicians appealed to Estonian population to make a choice for high living standards and increased level of security - an image of (Northern) Europe. ${ }^{181}$ Portraying Estonia as a part of the Nordic countries, as a potential member of the prosperous and stable EU, politicians reinforced the positive Estonia's Self as well as positive European/Nordic Other by making references to the negative image of the Russian (Soviet) Other. Estonians were "no longer members of suffering, miserable and helpless

\footnotetext{
${ }^{178}$ Laar, Tallinn, 18 January 2001.

179 " It's hard to imagine how we without these supports could repair and build roads, advance environmental protection, promote rural life, supply Estonian villages and cities with pure drinking water, or solve other problems left by the years of occupation" (Arnold Rüütel, TV Address on the Eve of Referendum. Tallinn [Estonia]: 13 September 2003).

${ }^{180}$ Arnold Rüütel, Signing of the EU Accession Treaty in Athens. Athens [Greece]: 16 April 2003.

181 "Otherwise such rich countries as Austria, Sweden and Finland wouldn't have joined the EU in its so far last enlargement round" (Rüütel, Tallinn,13 September 2003).
} 
nation, but of a nation capable of successful integration with the West."182 Estonia's economic success and achievements in the filed of Information and Communication Technologies development were seen as preconditions assuring Estonia potential in the Western Europe.

The "success story" and innovative achievements of Estonia caused a transformation of the dominant national narrative. From the recent victim of the Soviet regime, from a "small country that could" Estonia was transformed into a "Baltic tiger", though "tiny", but still a "tiger." 183 That new image was strong enough to challenge the old foundational narrative which placed the First republic of Estonia at the heart of the nation and its national pride. Since then, the main expression of Estonia's national pride was its incredible economic success. ${ }^{184}$ In order for national sovereignty to survive and flourish, this new source of national pride should be secured. ${ }^{185}$ Membership in the EU provided the best opportunity for national pride that time. Estonia was proud of its success and the rhetoric of political elite changed to reflect this. Before, in the core of Estonia's discourse of "returning to Europe" was a strategy to be "the best student in the class" who was able to learn and adopt European standards very quickly and successfully. Estonia's self-image of a "tiny tiger" increased the country's self-confidence; now the Estonian political elite claimed that the country could and should not only to learn from Europe, but also teach Europe. Estonia wanted to share its experience and achievements with other countries, foremost with less developed Commonwealth of Independent States ${ }^{186}$ and Balkan countries, but also with developed Western countries. According to Lehti, it has been argued that Estonians and other Balts were more efficient and more successful in carrying out their reforms than the old, more established Western European states. ${ }^{187}$ Also, Estonia was definitely ahead of many them in some innovative sectors, such as development of

\footnotetext{
${ }^{182}$ Laar, Budapest, 1 November 2000.

${ }^{183}$ Kristiina Ojuland, Tiny Tigers Will Always Be Tigers. Berlin [Germany]: 15-16 November 2002.

184 "We see also our economy developing and trade flowing towards the European Union. Definitely, we see the achievements in culture and science, which promoted and familiarised us from Lapland to Portugal. It is amazing that small Estonia has accomplished all this" (Arnold Rüütel, Remarks at the Flag-raising Ceremony to Mark in front of Kadriorg Palace. Tallinn [Estonia]: 1 May 2004).

${ }^{185}$ Lehti, 2006, 83.

186 The Commonwealth of Independent States (CIS) is a regional organization of the former Soviet Republics.

${ }^{187}$ Lehti, 2006, 83.
} 
Information and Communication Technologies. As the minister of foreign affairs, Kristina Ojuland, has argued: "Estonia has on the basis of its reforms and progress acquired enough self-confidence to be able to address with an innovatory spirit also the matter of reforming the European Union [...] The future development of Europe will be dependent upon our joint endeavours as IT tigers." 188 Ojuland also added that Estonia's progress and its influence on other countries would improve Europe's competitiveness with the United States.

The president Rüutel was of the same opinion about the potential advantages that Estonia could bring to Europe. A decade ago, Estonia had already played a great role in transforming Europe and turning it to the path of democratic development. According to Rüütel, the Baltic States were among the main contributors to the fall of the Berlin Wall and the collapse of the Soviet Union. Restoring their own independence, the Balts set prerequisites for other nations to become independent. ${ }^{189}$ Ten years after, the situation repeated. A "tiny Baltic tiger" Estonia again was establishing preconditions for transformation of Europe, now from the perspective of implementation and propagation of knowledge-based development: "we bring into the European Union our knowledge and experience, our traditions and culture. This will enrich the Union." 190

Talking about the main reasons that determined success for Estonia, Prime Minister Laar argued that those laid not in the some external conditions, but in the change of people's mentality. Typical characteristics of the Soviet era - collectivism and persecution of nonstandard (non-socialist) way of thinking - were replaced by new patterns of individual thinking and opportunity to take initiatives and resolve one's own problems individually. The spirit of Estonians, "spoiled by the socialist heritage" was now on its way to normality, and integration with the EU could create conditions to maintain that

\footnotetext{
${ }^{188}$ Ojuland, Berlin, 15-16 November 2002.

189 "Thus, the Berlin Wall came down in November 1989 - a year after Estonia's declaration of sovereignty and in another year Germany was reunified. These epoch-making events launched a new era in Europe, although the changes had started already two years ago. The above examples should indicate the significance of the Baltic states in the events transforming Europe [...] Furthermore, in the events turning half of Europe to the path of democratic development, the role of the Baltic states was significant" (Arnold Rüütel, Address at St John's College of Oxford University. Oxford [United Kingdom]: 12 November 2002).

${ }^{190}$ Rüütel, Athens, 16 April 2003.
} 
normality. ${ }^{191}$ The minister of foreign affairs Ilves also admitted that the mentality and psychology of Estonians had started to change. As an example, Ilves referred to a case that happened with one professor from the University of Tartu. ${ }^{192}$ That case was an indicator that with every new generation, the remembrance and knowledge of young Estonians about the Soviet past of their country is declining.

However, such developments are not necessarily positive. Every nation should know its history, both positive and negative periods of it. As a famous Estonian poet, Juhan Liiv, said: "he who does not know his past lives without a future." A number of Estonian politicians used this aphorism in their speeches. ${ }^{193}$ This phrase demonstrates Estonia's stance in memory politics and explains the behaviour of its political elite. Complementing that quotation by a saying of the well-known in memory studies Spanish American poet and philosopher George Santayana: "those who cannot remember the past are condemned to repeat it," it is possible to understand the main "doctrine" Estonian memory politics is based on. As the Prime Minister of Estonia, Juhan Parts, noticed: "we must look into our past in order to see where we have arrived today. We must also look into our past in order to determine our future." ${ }^{194}$ The attempts of the Estonian political elite directed on bringing communist crimes into public discussion in order to investigate them, evaluate their influence and possible implications confirm the functioning of that doctrine. Estonia does not want those crimes to be repeated in any place of the world. Also, examination and international recognition and condemnation of communist crimes are important for the Estonia's self-identification. Estonia can not employ the same principle as the great European powers did after the defeat of Nazism, Estonia can not forgive the injustice done

\footnotetext{
${ }^{191}$ Laar, Budapest, 1 November 2000.

192 "Minds have already begun to change. Young people today don't even remember what the Estonian Soviet Socialist Republic "flag" looked like, for instance. A Tartu University professor I know explained that he had told an anti-Soviet joke in his class, and then added that had he told that joke a few years earlier he would have been hauled in front of the party. A student raised her hand and asked, "Mr. Professor, which party?" (Ilves, Tallinn, 27 November 1999).

${ }^{193}$ Juhan Parts, Lecture at the University of Glasgow. Glasgow [United Kingdom]: 18 October 2004; Toomas Hendrik Ilves, Speech at the Ceremony Commemorating the $90^{\text {th }}$ Anniversary of the Tartu Peace Treaty. Tartu [Estonia]: 2 February 2010.

${ }^{194}$ Parts, Glasgow, 18 October 2004.
} 
to it or reconcile with those who committed crimes against its people. ${ }^{195}$ Despite the fact that the Soviet Union did not exist for twenty years already, despite all attempts made by Estonian political elite to marginalize the Soviet past of their country by their economic success or the status and image of a European country, despite all claims of Estonia presenting the Soviet period as illegal, as an aberration - it might not help since the Soviet legacy will nonetheless subconsciously dominate their self-identification. ${ }^{196}$ Therefore, the issue of the Soviet inheritance in former communist republics - current members of the EU should be examined, resolved and reconciled on the European level. As the Prime Minister Parts fairly noticed, "Europe cannot have two memories, two histories."197 Parts demonstrated the great confidence that all members of the EU "should adopt a common position regarding all totalitarian regimes and the crimes that they committed."198

Estonia's attempts to counterpoise the Nazi and Soviet crimes were expressed not only in their equal investigation and condemnation, but also commemoration. In 2002, following the example of other EU member states the government of Estonia made a decision to declare the $27^{\text {th }}$ of January as a memorial day for the Holocaust and other victims of crimes against humanity. Together with this statement, the Prime Minister referred immediately to the importance of paying attention to the victims of the Communist regime on the mourning days on March $25^{\text {th }}$ and June $14^{\text {th }} .99$

An interesting example which confirms the divergent vision of history in Estonia and some Western European states was reflected in a speech by the Estonian Prime Minister Mart Laar. According to Laar, the "greatest victory in the 20th century" was the final demise of the criminal communist regimes in Central and Eastern Europe. ${ }^{200}$ Whereas in the Western part of Europe the greatest victory of the $20^{\text {th }}$ century was definitely defeat of Hitler and Nazism in May 1945. It demonstrates the obvious gap in interpretation of history of the $20^{\text {th }}$ century in the countries of Western and Central and Eastern Europe. For

\footnotetext{
${ }^{195}$ Toomas Hendrik Ilves, Today is a Day for Remembering all of the Victims of World War II. Tallinn [Estonia]: 08 May 2010.

${ }^{196}$ Lehti, 2006, 86.

${ }^{197}$ Juhan Parts, Speech on the occasion of the 86th Independence Day. Tartu [Estonia]: 23 February 2004.

${ }^{198}$ Juhan Parts, Speech at the European People's Party Congress. Brussels [Belgium]: 5 February 2004.

${ }^{199}$ The government designates a memorial day for the Holocaust and other victims of crimes against humanity. Tallinn, [Estonia]: 6 August 2002.

${ }^{200}$ Laar, Budapest, 1 November 2000.
} 
the former, the foundation for collective memory lies in the experience of the World War II period; for the latter, the postwar Soviet experience is more significant than that of World War II. However, in order to tie Western Europe with Estonia's own narrative, as well as to demonstrate the unity that appeared between Western and Central and Eastern Europe when fighting against the communist enemy, Laar expressed the common Estonian gratitude towards the Western Powers "who refused to be blinded by the Red Smog and pressed [the] Soviet Union to the corner" and "broke the backbone of the Soviet Empire."201

\section{Stage IV: Membership}

Estonia's entering into the EU in May 2004 was one of the most important chapters of its history and definitely the most influential turning point in the Estonia's discourse of European integration. According to the foreign minister Ojuland, it signified the end of country's status of being a "nation in transition." 202 However, it was not "the end of history" for Estonia, but rather a beginning of a completely new and much more demanding era, entering into the phase full of greater responsibilities and commitments. ${ }^{203}$ The Prime Minister Parts called the eastern enlargement of the EU as "the correction of an historic injustice," claiming that "with this step, the historic debt [to Estonia] has been repaid."204

During that stage, Estonia continued with pursuing its main strategies of the "success story" and "the best student in the class." At that time, emphasis on the innovative character of Estonia even increased. The Estonian political elite presented country's aspiration to bring about and spread its achievements, fresh new ideas of innovation to other European States as an attempt to bolster the competitiveness of Europe. ${ }^{205}$ Estonia wanted to prove that not only new member states benefited from joining the EU, but the

\footnotetext{
${ }^{201}$ Laar, Budapest, 1 November 2000.

${ }^{202}$ Kristiina Ojuland, Address to the Riigikogu on behalf of the Government of Estonia. Tallinn [Estonia]: 8 June 2004; Kristiina Ojuland, Address at the Event "Dialogue with a New Member State: Estonia." Vienna [Austria]: 28 September 2004.

203 Ojuland, Vienna, 28 September 2004.

204 Juhan Parts, Speech at the Norwegian Nobel Institute. Oslo [Norway]: 15 February 2005.

205 Juhan Parts, Speech in Natolin: Competition and competitiveness in Europe. Warsaw [Poland]: 29 September 2004.
} 
EU itself received a number of advantages after the eastern enlargement. The political elite portrayed enlargement as incredible improvement of security and prosperity that "the divided Europe was never able to provide" and presented new members not as a burden or challenge for the "old" Europeans, but as a solution to some problems of the EU that now were referred as "our [common] problems.",206

Behind the tendency to increase its own significance for Europe and the EU was also Estonia's dissatisfaction with the status of a "new" member. Before membership, the division of Europe into "old" and "new" parts was acceptable for Estonia (it was better than distinction between "West" vs "East" or "true" vs "false" Europeans). After entering the EU, the main goal of Estonian political elite was to eliminate that distinction: "talk of "old" and "new" members will be confined to the pages of history."207 For Estonia, the term "new" Europe was a reference to its "otherness" in Europe, to its previous status of being "European but not quite European." 208 It reminded Estonia of its Soviet inheritance, postSoviet identity and mentality, referred to its backwardness. In other words, those were the symbols Estonia wished most to get rid of or at least marginalize by "returning to Europe" and membership in the EU.

That strategy has been dominant in Estonia's political discourse during the first years of membership period. As the president of the Republic Toomas Hendrik Ilves has stressed in his speech to the Estonian Jurists' Forum in September 2010, Estonia has finally returned to Europe. ${ }^{209}$ The President pointed out that from a poor country, "strangled by communism", Estonia changed into a democratic state that does not belong any more to a problematic region requiring special care and a "hand to be held [sic]." ${ }^{210}$ Now Estonia is the country that not only has an obligation to follow standards prescribed by others but also participate in establishment of rules.

\footnotetext{
${ }^{206}$ Kristiina Ojuland, Address at the Conference "New Europe 2020": The New Role of Governments and the EU in Wider Europe. 27 August 2004.

${ }^{207}$ Parts, Warsaw, 29 September 2004.

${ }^{208}$ Lehti, 2006; Mälksoo, 2009, 655.

209 "I have repeatedly - most recently in opening the autumn session of parliament - stressed that Estonia has returned to Europe. We no longer need to follow rules established in our regard by others. From now on, we take part in setting those rules" (Toomas Hendrik Ilves, Speech on $31^{\text {st }}$ Estonian Jurist's Forum. Tartu [Estonia]: 30 September 2010).

${ }^{210}$ Toomas Hendrik Ilves, Interview to "Eesti Päevaleht”: "Estonia's Future will be Determined by the Success of our Foreign Policy and Diplomacy. 14 January 2010.
} 
Despite the fact that there is no need any more for Estonia to "follow rules established in our regard by others," Ilves admitted that Estonia still remains "a policytaker, not a policy-maker" in the EU decision-making process. ${ }^{211}$ One area Estonia definitely would like to be a "policy-maker" is related to the introduction of legislation on official recognition and condemnation of the communist crimes. When Estonia joined the EU, its national memory became a part of the European collective memory. Though Estonia has more opportunities now to bring that issue to the wider debate as well as claim that "our history is your history and your history is our history" and demand from the European and international community to pay more attention to the communist crimes, in fact the activity of Estonian politicians is quite low. ${ }^{212}$ For example, when comparing the behaviour of the members of the European Parliament from three Baltic States, Lithuanian representatives show much more initiative with regards to the communist crimes topic than Estonians do.

However, the situation is different on the domestic level. Politicians often appeal to the illegality of the Soviet period and necessity to recognize the atrocities committed by the Soviet regime. Right after joining the EU, in May 2004, the Prime Minister of Estonia Juhan Parts honoured Estonia's past and strength of Estonians who survived the "red night" admitting that the Estonians who just entered the EU are "indebted to [their] past" and persistence of their predecessors this new status. Parts, commemorating the victims of the Soviet regime and signing a declaration which condemned the communist regime, also appealed to European community, claiming that "Europe must condemn communism just as it condemned Nazism during the Nuremberg trials." 213 Referring to the crimes of the Soviet regime in Estonia as a "communist holocaust", Parts noted that Estonia has to investigate, explain and clarify the brutality of the totalitarianism to the larger European

\footnotetext{
211 "The expression "policy-taker" can be construed as someone who is dragged along or hanging behind, while the expression "policy-maker" can be interpreted as those who are pace setters or decision-makers. It is quite obvious that a self-respecting country, no matter how big or large its area and population is, does not want to be dragged along by anyone. However, only those with their own opinion and interests, and the guts required to present and defend these ideas and interests, will make it to the ranks of decision-makers" (Ilves, 14 January 2010).

${ }^{212}$ Ilves, 14 January 2010.

${ }^{213}$ Juhan Parts, Speech in Valga. Valga [Estonia]: 21 May 2004.
} 
community. ${ }^{214}$ He pointed out the importance of the condemnation of communism as a criminal regime not only in different international organizations (such as the European Parliament), but also in the minds of the international public, of Western civilization.

The minister of foreign affairs, Kristiina Ojuland, came out with a less emotional and rather pragmatic position towards the necessity of recognition of the Soviet inheritance. Ojuland pointed out that both Estonia's and the EU's relations with the Russian Federation would be positively influenced "by the international condemnation of the crimes committed by Communist regimes, and by Russia's admittance of the past." ${ }^{215}$ The current president of Estonia, Toomas Hendrik Ilves, has contributed significantly to international recognition of the Soviet crimes. In 2007, the President suggested an idea to find out and commemorate all Estonian victims of communism, by name. ${ }^{216}$ Another initiative of Ilves was foundation of the Estonian Memory Institute. The main purpose of the institute was to educate Estonian public about the human rights situation and their violation in Estonia under Soviet occupation as well as examine the implication of those violations for Estonia. ${ }^{217}$ Also, the institute should bring this subject onto the international stage and facilitate discussion of the communist heritage and crimes in Europe. Ilves also played a role in foundation of the International Virtual Museum of Communism Victims in Washington D.C. Estonia was the first country which supported financially the museum, whose mission was to inform the international public about the communist history, heritage, and crimes. ${ }^{218}$ In 2008 , the President of Estonia and the former President of Poland stood out with the joint declaration calling European countries to create an international commission to assess and investigate communist crimes in Europe. According to Ilves and Kaczynski, that problem had always been treated as a secondary "historical" issue in Europe, despite the fact that it affected nearly one fourth of European citizens. Appealing to the common compliance to the

\footnotetext{
214 Juhan Parts, Speech on the Role of Estonian Lawyers at the $28^{\text {th }}$ Estonian Lawyers' Days. Tartu [Estonia]: 22 October 2004.

215 Ojuland, Tallinn, 8 June 2004.

216 "Name them and remember" (The Economist, 20 September 2007).

${ }^{217}$ Estonian Institute of Historical Memory 04 October 2010.

${ }^{218}$ Prime Minister Ansip handed over Estonian support for establishing the Virtual Museum of Communist Crimes, Washington 29 November 2007. According to Mr. Ansip, Estonia contribution was a sign indicating willingness of the country to explain communist crimes and also encourage other countries to support such initiatives.
} 
principles of moral right and justice, the Presidents argued that "only in this way can we heal the remaining scars that even today divide us."219

Though Estonia's joining the EU has significantly increased its aspirations to bring communist crimes into surface, at the same time Estonia has tried to demonstrate respect towards the common principles of the European collective memory as well. In contrast to the Western European countries, the end of World War II brought Estonia neither freedom nor peace. The $8^{\text {th }}$ of May 1945 celebrated in Western Europe as the Victory Day over Nazism has a totally different meaning for Estonians (the beginning of the Soviet occupation). Despite this fact, the Estonian political elite always showed its solidarity with other members of the EU in recognizing the significance of that day for Europe. Commemorating all victims of the war together with its European counterparts, Estonian politicians often appeal to reconciliation as a primary means to overcome the painful past. ${ }^{220}$ As the Estonian Prime Minister Andrus Ansip said, citing the second president of Estonia, Lennart Meri: "all wars end twice. First - when armed conflict ends. Second when enemies reconcile." ${ }^{221}$ The current president of Estonia Ilves amended that argument by claiming that for Estonia World War II ended on $31^{\text {st }}$ of August 1994, when foreign troops left the Estonian soil. ${ }^{222}$ At the same time, Ilves stressed that people of Estonia are going neither to forget the injustice that occupation forces did to their country nor "reconcile with those who committed crimes against their own and other peoples during the war.",223

Another aspect of memory politics that distinguishes Estonia from the rest of Europe is the importance and meaning of the Holocaust. In contrast to Western Europeans, who perceive the Holocaust as universal, deserving a status of the "foundational event" of

\footnotetext{
${ }^{219}$ Toomas Hendrik Ilves, Joint Declaration of the Presidents of the Republic of Poland and the Republic of Estonia. 18 March 2008.

${ }^{220}$ Ilves, Tallinn, 08 May 2010.

${ }^{221}$ Andrus Ansip, Speech at the Reception for the Diplomatic Corps Dedicated to the end of World War II in Europe. 8 May 2005.

${ }^{222}$ Ilves, Tallinn, 08 May 2010.

${ }^{223}$ Ilves, Tallinn, 08 May 2010.
} 
the European collective memory, in Estonia the Holocaust gets little attention and has never become a subject of larger debate. ${ }^{224}$ During World War II, Estonia was the only country which got a label "judenfrei" (free of Jews) at the Wannsee Conference in 1942, when the fate of European Jewry was officially decided. ${ }^{225}$ In fact, the Jewish community in Estonia was small and indiscernible; it could explain why many Estonians consider the Holocaust as a superimposed discourse without any connection to their country. ${ }^{226}$ Also, under the communist regime, the mass extermination of the Jewish population was presented by the Soviet propaganda machine as murders of peaceful Soviet citizens by Nazi occupiers.

The Holocaust posed a threat to the Estonian national narrative of sufferings under communist rule, as the Jews, marginalized as a minority, claimed the status of victims, otherwise assigned for the titular population. ${ }^{227}$ The myths of Judeo-Bolshevism have been quite strong in Estonia. Those stereotypes and perceptions of the Holocaust carried over into the post-communist transition period. ${ }^{228}$

During the last stages of post-communist transition and European integration (the periods of "negotiations" and "membership") the Estonian political elite always showed its own Europeaness and adherence to the Europeans norms, traditions and foundations. As the Holocaust has a great significance for European collective memory and history, Estonia also demonstrated its solidarity with that issue. Europe is a positive Other for Estonia, and the latter is trying to adopt different European practices and norms as a role model, as a standard to aspire. Estonia takes part in commemoration of the innocent victims on the International Holocaust Remembrance Day on January $27^{\text {th }}$, the Holocaust is taught during history lessons as a part of Estonia's national core curriculum for basic and secondary education, Estonia has participated in the Task Force for International Cooperation on

\footnotetext{
${ }^{224}$ Inge Melchior and Oane Visser, "Voicing past and present uncertainties: The relocation of a Soviet World War II memorial and the politics of memory in Estonia," Focaal 59 (2011): 46.

${ }^{225}$ The Final Solution of the Jewish Question, or a program of mass extermination of the European Jews, was discussed and finally adopted at the Wannsee Conference.

${ }^{226}$ Anton Weiss-Wendt, "Why the Holocaust Does Not Matter to Estonians" in Contested and Shared Places of Memory: History and Politics in North Eastern Europe, ed. by Jörg Hackmann and Marko Lehti (London: Routledge, 2009), 94.

${ }^{227}$ Weiss-Wendt, 111.

${ }^{228}$ Weiss-Wendt, 94.
} 
Holocaust Education, Remembrance and Research since 2007. ${ }^{22}$ However, the Estonian political elite often uses the term Holocaust to draw more attention to painful issue of the Soviet crimes, and necessity of their recognition and remembrance worldwide. The most common ways are drawing parallels between the sufferings of the Jews under Holocaust and Estonians under communism (as, for example, Parts' references to the "communist Holocaust" mentioned above). The practice to mention communist crimes and sufferings of the Estonian people when mourning or commemorating the Holocaust or World War II victims are also widespread. The Prime Minister Ansip while paying tribute to the victims of the Nazi regime during the International Holocaust Remembrance Day did not fail to mention that "Estonia too suffered during and after the Second World War under totalitarian regimes and we paid for this with our independence." 230 The President Ilves compared the Soviet vision of the occupation as the liberation of Estonia ${ }^{231}$ with the concept of Holocaust denial. ${ }^{232}$ An important element of the Holocaust debate is Estonians' collaboration with occupiers, in particular, their role in the Holocaust. The Estonian political elite do not deny that during World War II there were Estonians who collaborated with the Nazis and took part in the Holocaust atrocities. ${ }^{233}$ However, the Estonian veterans who had served in the German army often present their cooperation with Germans as a struggle "against Bolshevism and for the restoration of Estonian independence."234

\footnotetext{
${ }^{229}$ Estonia Becomes Member of Task Force for International Cooperation on Holocaust Education, Remembrance and Research, 05 December 2007.

${ }^{230}$ Andrus Ansip, Statement on International Holocaust Remembrance Day. 27 January 2007.

${ }^{231}$ Russian memory narrative.

232 "It is quite obvious that an Estonian can by no means accept as his liberator a regime that has committed mass crimes against humanity. It must be realised that atrocities were perpetrated in Estonia and to call them liberation is on par with the negation of the Holocaust" (Toomas Hendrik Ilves, Interview to "Eesti Päevaleht": "We Have Too Few Surviving Men." Tallinn [Estonia]: 22 February 2008).

233 "These reminders are painful for all humanity and particularly painful for this generation of Estonians who, free again after years of suffering under the Nazi and Soviet occupations, have opened up to the world and recognized that there were also Estonians among those who collaborated with the Nazis and participated in committing the murders of Holocaust" (Siim Kallas, Remarks at the US Capitol. Washington, D.C. [United States]: 4 September 2002).

${ }^{234}$ Melchior and Visser, 39.
} 
To sum up, Estonia's discourse of "returning to Europe" is a good example that demonstrates the interaction between memory and political power. The conducted analysis of speeches showed the ability of politicians to direct the discourse on European integration relying on and making appeals to the collective memory of Estonian people. The findings of the analysis proved the assumption of the study. In fact, the Estonian political elite representatives were able to present the Soviet experience of their country in the context of European integration as a mean to break away and to maintain the continuity with the communist past. In the former case, politicians attempted to distance Estonia from its Soviet past stressing the Europeaness of the country and contrasting the images of positive Self (Estonia) and positive Other (Europe/Nordic countries) to the negative Other (Russia/the Soviet Union). At the same time, the political elite constantly recalled the Soviet regime demanding international recognition of the communist crimes.

Furthermore, the Estonian politicians integrated successfully the discourse of European integration into the dominant memory narrative of the nation. As Heidemarie Uhl claims, political influence might go even further and transform collective memory narrative and collective identity within the frame of social power structures they created. ${ }^{235}$ Estonia's case confirmed this argument. During the different stages of post-communist transition, the Estonian political elite representatives have replaced the backward-looking political discourse by forward-looking. If in the beginning stages their main arguments directed on distancing Estonia from its Soviet past and supporting Europeaness of the country were appeals to the legal continuity with the pre-war First Republic, then in the following phases the primary legitimating source was future-oriented image of the innovative nation. In fact, Estonia's example has demonstrated that memory could perform as a "symbolic" and "structural" power in politics.

${ }^{235}$ Uhl, 60. 


\section{CONCLUSION}

Estonia's post-war national memory narrative is divergent from the European collective memory narrative. If the end of the War meant victory and peace for Western Europeans, for the Eastern part it marked the beginning of almost half of a century of occupation under the communist regime. After the collapse of the Soviet Union, Estonia took the road of "returning to Europe," or "returning to the West." First of all, it represented Estonia's attempts to gain recognition of the international community to its status of independent state. Later, that foreign policy aspiration received sharper focus, reflecting Estonia's efforts towards membership in the EU. Estonia, "the best student in the class," has always had an image of a fast learner of European practices and one of the most eager candidates to join the EU. The main reasons for such behaviour were economic, and undoubtedly, security calculations, since Estonia is a small periphery state which has a direct border with the large and powerful Russian Federation, its former oppressor. Besides the abovementioned factors there were also some psychological predicaments. Estonia did not want to have a status of post-Soviet Republic and be associated with the Soviet mentality, backwardness and other characteristics of a "false" Europe. The country wished to "return to Europe," to become a "normal," "true" European state.

The main purpose of this study was to examine the role of the Soviet legacies and national memory on the formation of political discourse and the process of European integration of Estonia. The study was built on the assumption that the Estonian political elite use the Soviet experience of the country for two separate purposes. On the one hand, the Soviet past was often presented as an accelerator of Estonia's achievement in the postSoviet period and as an indicator of the "Europeaness" of Estonia. A status of the "true" European state allowed politicians to distance their country from the backward, undemocratic Russia and to replace the Soviet past of Estonia by European present. On the other hand, the Soviet experience induced the Estonian political elite to demand international recognition and condemnation of the communist crimes as it was done with the Nazi crimes after World War II. 
The study aimed to clarify the abovementioned assumption and find out whether it was justified or not. The main goal of the analysis was to observe the dynamic of postcommunist development of Estonia and formation of political discourse of the country in the transitional period through the prism of memory politics. The empirical data for the analysis was a selection of speeches delivered by three representatives of the high politics: the head of state of the Republic of Estonia - the President, the head of government - the Prime Minister, and the head of the Foreign Ministry - the Minister of Foreign Affairs. The period of analysis, 1991-2011, was divided into four stages: "de-Sovietization," "application," "negotiation," and "membership." The analysis demonstrated different trends in framing the political discourse during each of those phases and also indicated some changes that appeared in the course of transitional period.

The findings of the analysis proved the research assumption. In fact, the Estonian political elite often appeal to the national memory of Estonians as well as the Soviet past of the country in order to legitimize certain political decisions, to emphasize or, on the contrary, avoid particular aspect of one or another event. The Soviet Union (and also the Russian Federation after the collapse of communism) has gained a stable position of the negative Other for Estonians and the collective memory of the nation. By contraposing negative Other to the positive Self, or positive Other (Europe, the European Union, Nordic countries) the Estonian political elite wished to distance the country from its Soviet past. The conceptual pair of positive Self/negative Other allowed politicians to emphasize even more some of the positive aspects related to Estonia's development in post-communist period as contrasted to the country's existence under the Soviet dominance. Also, such contradistinction provided Estonia with credentials to present itself as a "true" European country, not a part of the "false" Europe, a former communist state. The contrast between positive Other and negative Other showed Europe and the European Union in the very positive light, as opposed to the totalitarian Soviet Union. Such comparison was sometimes used when the political representatives wanted to legitimize some harsh reforms or EUrelated policies that might cause dissatisfaction among population. Sometimes, the Soviet 
experience was presented as a mean to justify some imperfections in Estonia's own policies. Most commonly, though, the negative Soviet experience was supposed to emphasize whether success of Estonia during the transitional period or reinforce the positive image of Europe with the main aim to shift the perception of Estonia as a postcommunist country and distance it from the Soviet past.

Another aspect of the Soviet past that Estonian politicians always stressed and tried to incorporate into the political discourse were communist crimes and demand for their international recognition and condemnation. Drawing attention on the illegality of the Soviet occupation that deprived Estonia's freedom and distanced the country from the "true" Europe for almost a half of a century, the Estonian politicians appealed to the European community to equalize communist crimes with Nazis' and reassure the proper investigation of the former.

The findings of the analysis showed a development that is seemingly a paradox. The Estonian political elite representatives attempted to move away and maintain continuity with the Soviet past at the same time. Those two lines have been running parallel during the whole post-communist period. Estonian politicians always stressed Estonia's belonging to Europe; Estonia's discourse on "returning to Europe" was in fact a return to its "natural home." In order to confirm the "Europeaness" of Estonia, elite representatives always emphasized in their speeches the common democratic values and traditions both Estonia and Europe were based on. Going back to $16^{\text {th }}$ and $17^{\text {th }}$ centuries, they constantly reminded about cultural ties connecting Estonia with Western European states. Even foreign dominance by those states was presented as positive and beneficial for Estonia. At the same time, politicians continued to emphasize the illegality of the Soviet occupation and the "age of Darkness" it brought to Estonians. Estonia's belonging to the family of three Baltic States - one of the strongest legacies of the Soviet past - was also marginalized, especially during the second and third stages of transition. Some of the representatives of the political elite denied the whole existence of such phenomenon as Baltic identity and tried to replace it by another regional affiliation, the Nordic or Scandinavian identity. 
The analysis also revealed some shifts in the political discourse - gradually, from the backward-looking it became transformed into forward-looking. If in the beginning of the transitional period Estonian politicians relied mainly on continuity with the First Republic 1918-1940 when framing the discourse, then after several years of development and series of successful reforms, the main focus started to move gradually from past towards future. The narrative looking back to history and praising the First Republic was replaced by a narrative of a future-oriented innovative nation. The change of strategies, or images Estonian politicians used to present the country, illustrated the shifts that appeared in the political discourse.

During the first, de-Sovietization, stage the country followed a strategy of "victimization." Stressing the illegality of Soviet occupation, the Estonian people's sufferings under the criminal communist regime, and referring to the Soviet period as to an era of "aberration," the Estonian political elite sought above all the international protection for the fragile status of their newly independent Republic. During the second stage, Estonia felt more confident. Successful economic and political reforms, and also admission of Estonia into the first wave of negotiations to join the EU transformed Estonia's image from the victim into "a small country that could." During the third stage, Estonia tried to consolidate its place and importance in Europe with further economic success and outstanding achievements in the field of Information and Communication Technologies, presenting itself as a "Baltic Tiger." In the fourth stage, Estonia continued with that image, stressing the innovative character and potential of Estonia. Now the country felt sufficiently confident, mature and developed to emphasize its willingness to transmit its achievements and "teach" Western European countries. Partly, it was done in order to eliminate still existing in Europe division into "old" and "new" members. Belonging to the group of "new" European states was seen by the Estonian political elite as a reference to "otherness" and a reminder of its Soviet past - one of the main labels Estonia wished to overcome and replace by its European present and future.

To counter the widespread fears that membership in the EU posed a threat to the national identity of the country, the Estonian political elite often emphasized the opposite 
trend. They argued that European integration and a status of a member actually have strengthened Estonian national identity. In case of a small country it might be really the case. The European Union provides more opportunities for Estonia to make itself heard and present its position internationally. The findings of this study provide a good basis whether for further research on the same topic or for extended investigation. For example, it is possible to add a component of identity to the existing framework and observe how three types of identity - national, regional and European - interact and influence each other in the case of Estonia. 


\section{BIBLIOGRAPHY}

\section{Books, chapters from the books, and articles:}

Alpan, Basak Z. "Intellectual and Political "Europe": Rupture or Continuity in Central Europe." In Central European history and the European Union: the meaning of Europe, edited by Stanislav J. Kirschbaum, 145-158. Basingstoke [England]: Palgrave Macmillan, 2007.

Assmann, Aleida. "Four Formats of Memory: From Individual to Collective Constructions of the Past." In Papers from the conference "The Fragile Tradition," Cambridge 2002. Volume 1, Cultural Memory and Historical Consciousness in the German-speaking World Since 1500, edited by Christian Emden and David R. Midgley, 19-37. Oxford: P. Lang, 2004.

Assmann Aleida. "Transformations Between History and Memory." Social Research 75 (2008): 49-72.

Assmann, Jan. "Collective Memory and Cultural Identity." in New German Critique 65 (1995): 125-132.

Bell, Duncan. “Agonistic Democracy and the Politics of Memory." Constellations 15 (2008): 148-166.

Bell, Duncan. "Mythscapes: Memory, Mythology, and National Identity." British Journal of Sociology 54 (2003): 63-81.

Berg, Eiki. "Local Resistance, National Identity and Global Swings in Post-Soviet Estonia.” Europe-Asia Studies 54 (2002): 109-122.

Cirtautas, Arista Maria and Frank Schimmelfennig. "Europeanisation Before and After Accession: Conditionality, Legacies and Compliance.” Europe Asia Studies 62 (2010): 421-441.

Diner, Dan. "Memory and Restitution: World War II as a Foundational Event in a Uniting Europe." In Restitution and Memory: Material Restoration in Europe, edited by Dan Diner and Gotthard Wunberg, 9-27. Berghahn Books, 2007.

Evans, Martin. "Memories, Monuments, Histories: The Re-thinking of the Second World War since 1989." National Identities 8 (2006): 317-348.

Henderson, Karen. "Exceptionalism or Convergence? Euroscepticism and Party Systems in Central and Eastern Europe." In Opposing Europe? The Comparative Party Politics of Euroscepticism. Volume 2, Comparative and Theoretical Perspectives, edited by Aleks Szczerbiak and Paul A. Taggart, 103-126. Oxford: Oxford University Press, 2008. 
Hirst William and David Manier. "Towards a Psychology of Collective Memory." Memory 16 (2008): 183-200.

Ilves, Toomas Hendrik. "Eesti Poliitika Euroopastumine.” Luup 6 (1997).

Also available online:

http://luup.postimees.ee/luup/97/06/sise2.htm (accessed 26.04.2011).

Irwin-Zarecka, Iwona. Frames of Remembrance: the Dynamics of Collective Memory. New Brunswick [N.J.]: Transaction Publishers, 1994.

Jarausch, Konrad H. and Thomas Lindenberger. "Contours of a Critical History of Contemporary Europe: a Transnational Agenda." In Conflicted Memories: Europeanizing Contemporary Histories, edited by Konrad H. Jarausch and Thomas Lindenberger, 1-22. Berghahn Books, 2007.

Judt, Tony. "The Past is Another Country: Myth and Memory in Post-War Europe." In Memory and Power in Post-War Europe: Studies in the Presence of the Past, edited by JanWerner Müller, 157-183. Cambridge University Press, 2002.

Jõesalu, Kirsti. "The Meaning of "Late Socialism": Analyzing Estonians' Post-Communist Memory Culture." Asia Europe Journal 8 (2010): 293-303.

Kaelble, Hartmut. "Identification with Europe and Politization of the EU since the 1980s." In European identity, edited by Jeffrey T. Checkel and Peter J. Katzenstein, 193-212. Cambridge: Cambridge University Press, 2009.

Kalmus, Veronika. "Is Interethnic Integration Possible in Estonia?: Ethno-Political Discourse of Two Ethnic Groups.” Discourse \& Society 14 (2003): 667- 697.

Kansteiner, Wolf. "Finding Meaning in Memory: A Methodological Critique of Collective Memory Studies." History and Theory 41 (2002): 179-197.

Kirschbaum, Stanislav J. Central European History and the European Union the Meaning of Europe. New York: Palgrave Macmillan, 2007.

Lauristin, Marju. "Contexts of transition." In Return to the Western world: Cultural and Political Perspectives on the Estonian Post-Communist Transition, edited by Karl Erik Rosengren, Marju Lauristin, and Peeter Vihalemm, 25-40. Tartu: Tartu University Press, 1997.

Lebow, Richard N. "The Memory of Politics in Postwar Europe." In The Politics of Memory in Postwar Europe, edited by Richard N. Lebow, Wulf Kansteiner, and Claudio Fogu, 1-39, Duke University Press, 2006. 
Leggewie Claus. "A Tour of the Battleground: The Seven Circles of Pan-European Memory." Social Research 75 (2008): 217-234.

Lehti, Marko. A Baltic League as a Construct of the New Europe. Frankfurt: Peter Lang, 1999.

Lehti, Marko. "Eastern or Western, New or False? Classifying the Balts in the Post-Cold War Era." In Wider Europe: Nordic and Baltic Lessons to Post-Enlargement Europe, edited by Fabrizio Tassinari, Pertti Joenniemi, and Uffe Jakobsen, 69-88. Copenhagen, Denmark: Danish Institute for International Studies, 2006.

Lehti Marko, Matti Jutila, and Markku Jokisipilä. "Never-Ending Second World War: Public Performances of National Dignity and the Drama of the Bronze Soldier." In Contested and shared places of memory, edited by Marko Lehti and Jörg Hackmann, 15-40. London: Routledge, 2010.

Lévinas, Emmanuel, and Seán Hand. The Levinas Reader. Oxford: Blackwell, 1989.

Made, Vahur. "Estonia and Europe: a Common Identity or an Identity Crisis?" In Post-Cold War Identity Politics: Northern and Baltic Experiences, edited by Marko Lehti and David. J. Smith, 183-198. London: Frank Cass, 2003.

Matthews, W. K. "The Background and Poetry of Gustav Suits. A Study in Estonian Symbolism."American Slavic and East European Review 9 (1950): 116-127.

Melchior, Inge and Oane Visser. "Voicing Past and Present Uncertainties: The Relocation of a Soviet World War II Memorial and the Politics of Memory in Estonia." Focaal 59 (2011): 33-50.

Mikkel, Evald and Andres Kasekamp. "Emerging Party-Based Euroscepticism in Estonia." In Opposing Europe? The Comparative Party Politics of Euroscepticism. Volume 1, Case Studies and Country Surveys, edited by Aleks Szczerbiak and Paul A. Taggart, 295-313. Oxford: Oxford University Press, 2008.

Mikkel, Evald and Geoffrey Pridham. "Clinching the "Return to Europe": The Referendums on EU Accession in Estonia and Latvia." West European Politics 27 (2004): 716-748.

Minow, Martha. Between Vengeance and Forgiveness: Facing History After Genocide and Mass Violence. Boston: Beacon Press, 1998.

Mälksoo, Maria. "The Discourse of Communist Crimes in the European Memory Politics of World War II." Ideology and Discourse Analysis Conference: Rethinking Political Frontiers and Democracy in a New World Order, Denmark: Roskilde University, 2008. 
Mälksoo, Maria. "The Memory Politics of Becoming European: The East European Subalterns and the Collective Memory of Europe." European Journal of International Relations 15 (2009): 653-680.

Mälksoo, Maria. The Politics of Becoming European: a Study of Polish and Baltic PostCold War Security Imaginaries. London: Routledge, 2010.

Müller, Jan-Werner, ed. Memory and Power in Post-War Europe Studies in the Presence of the Past. Cambridge: Cambridge University Press, 2002.

Neumann, Iver B. Uses of other: “The East” in European Identity Formation. Manchester: Manchester University Press, 1999.

Olick, Jeffrey K. "Collective Memory: The Two Cultures.” Sociological Theory 17 (1999): 333-348.

Onken, Eva-Clarita. Forms of Collective Memory and How They Relate to Power, Identity and Myth (a lecture at Winter school on Politics of Memory, February 27 - March 1). Tartu: 2008.

Onken, Eva-Clarita. "Memory and Democratic Pluralism in the Baltic States - Rethinking the Relationship.” Journal of Baltic Studies 41 (2010): 277-294.

Onken, Eva-Clarita. "The Baltic States and Moscow's 9 May Commemoration: Analysing Memory Politics in Europe.” Europe Asia Studies 59 (2007): 23-46.

Petersoo, Pille. "Reconsidering Otherness: Constructing Estonian Identity." Nations and Nationalism 13 (2007): 117- 133.

Piirimäe, Helmut. "Historical Heritage: the Relations Between Estonia and Her Nordic Neighbors." In Return to the Western world: Cultural and Political Perspectives on the Estonian Post-Communist Transition, edited by Karl Erik Rosengren, Marju Lauristin, and Peeter Vihalemm, 43-72. Tartu: Tartu University Press, 1997.

Pääbo, Heiko. "Estonian Transformation. From an Eastern Outpost in the West to a Western Outpost in the East." In Cultural Transformations After Communism Central and Eastern Europe in Focus, edited by Krzysztof Stala and Barbara Tornquist-Plewa, 253-279. Lund: Nordic Academic Press, 2011.

Pääbo, Heiko. Potential of Collective Memory Based International Identity Conflicts in Post-Imperial Space. Comparison of Russian Master Narrative with Estonian, Ukrainian and Georgian Master Narratives. Tartu: Tartu University Press, 2011. 
Rousso, Henry. "History of Memory, Policies of the Past: What For?" In Conflicted Memories: Europeanizing Contemporary Histories, edited by Konrad H. Jarausch and Thomas Lindenberger, 23-37. Berghahn Books, 2007.

Smith, David J."The Devil and the Deep Blue Sea": European Integration, National Identity and Foreign Policy in Post-Communist Estonia." In Ideology and National Identity in Post-Communist Foreign Policies, edited by Rick Fawn, 156-177. London: Frank Cass, 2004.

Smith, Rogers M. Stories of Peoplehood: the Politics and Morals of Political Membership. Cambridge: Cambridge University Press, 2003.

Snyder, Timothy. "Memory of Sovereignty and Sovereignty Over Memory: Poland, Lithuania and Ukraine, 1939-1999." In Memory and Power in Post-War Europe: Studies in the Presence of the Past, edited by Jan-Werner Müller, 39-58. Cambridge University Press, 2002.

Stoltenberg, Steven. "Latvia, Lithuania, and Estonia: Determined Euro-Atlantists." In The European Union and the Member States, edited by Eleanor E. Zeff and Ellen B. Pirro, 411441. [S.1.]: Lynne, 2006.

Tamm, Marek. "History as Cultural Memory: Mnemohistory and the Construction of the Estonian Nation." Journal of Baltic Studies 39 (2008): 499-516.

Therborn, Göran. European Modernity and Beyond: the Trajectory of European Societies, 1945-2000. London: Sage Publications, 1995.

Uhl, Heidemarie. "Memory Culture - Politics of History. Some Reflections on Memory and Society." In Politics of Collective Memory: Cultural Patterns of Commemorative Practices in Post-War Europe, edited by Sophie Wahnich, Barbara Lášticová, and Andrej Findor, 57-65. Berlin: Lit, 2008.

Weiss-Wendt, Anton. "Why the Holocaust Does Not Matter to Estonians." In Contested and Shared Places of Memory: History and Politics in North Eastern Europe, edited by Jörg Hackmann and Marko Lehti, 94-115. London: Routledge, 2009. 


\section{Political speeches and statements taken from:}

The webpage of the President of the Republic of Estonia, www.president.ee

The webpage of the Estonian Government, www.valitsus.ee

The webpage of the Estonian Ministry of Foreign affairs, www.vm.ee

Ansip, Andrus. Speech at the reception for the Diplomatic Corps dedicated to the end of World War II in Europe. 8 May 2005.

Ansip, Andrus. Statement on International Holocaust Remembrance Day. 27 January 2007.

Ilves, Toomas Hendrik. Interview to City Papers. Tallinn [Estonia]: 27 November 1999.

Ilves, Toomas Hendrik. Estonia as a Nordic country. Stockholm [Sweden]: 14 December 1999.

Ilves, Toomas Hendrik. Interview to "Eesti Päevaleht”: "We Have Too Few Surviving Men.” Tallinn [Estonia]: 22 February 2008.

Ilves, Toomas Hendrik. Joint Declaration of the Presidents of the Republic of Poland and the Republic of Estonia. 18 March 2008.

Ilves, Toomas Hendrik. Interview to "Eesti Päevaleht": "Estonia's Future will be Determined by the Success of our Foreign Policy and Diplomacy.” 14 January 2010.

Ilves, Toomas Hendrik. Speech at the Ceremony Commemorating the $90^{\text {th }}$ Anniversary of the Tartu Peace Treaty. Tartu [Estonia]: 2 February 2010.

Ilves, Toomas Hendrik. Today is a Day for Remembering All of the Victims of World War II. Tallinn [Estonia]: 08 May 2010.

Ilves, Toomas Hendrik. Speech on $31^{\text {st }}$ Estonian Jurist's Forum. Tartu [Estonia]: 30 September 2010.

Laar, Mart. Lecture at the French Institute of International Affairs in Paris. Paris [France]: 10 April 2000.

Laar, Mart. Transition and the Consolidation of Democracy. The Case of Central Europe (1990 - 2000). Budapest [Hungary]: 1 November 2000.

Laar, Mart. Preparations for Accession of Estonia to the European Union. Tallinn [Estonia]: 18 January 2001.

Kallas, Siim. Remarks at the US Capitol. Washington, D.C. [United States]: 4 September 
2002.

Luik, Jüri. Remarks at the Meeting of Defence and Foreign Ministers of the Western European Union. Luxembourg: 9 May 1994.

Luik, Jüri. Quo Vadis, Estonian Foreign Policy? Roosta [Estonia]: 11-12 September 1994.

Meri, Lennart. Speech at the Reception for the Members of the Finnish Foreign Ministry and the Corps Diplomatique. Helsinki [Finland]: 9 October 1992.

Meri, Lennart. New Year's Address to the Estonian People. Tallinn [Estonia]: 31 December 1992.

Meri, Lennart. Speech at The Inaugural Conference Of The Baltic Institute For Strategic And International Studies. Tallinn [Estonia]: 16 December 1993.

Meri, Lennart. Address at the 1995 Plenary Meeting of the Trilateral Commission. Copenhagen [Denmark]: 22 April 1995.

Meri, Lennart. Address at the Carnegie Endowment for International Peace. Washington, D.C. [United States]: 19 October 1995.

Meri, Lennart. Address at a Fundraising Dinner for the Baltic Studies Center. Seattle, Washington [United States]: 31 October 1995.

Meri, Lennart. Speech at the 78th Independence Day Celebrations. Tallinn [Estonia]: 24 February 1996

Meri, Lennart. Remarks at the Jagellonia University of Krakow. Krakow [Poland]: 30 April 1998.

Ojuland, Kristiina. Tiny Tigers Will Always Be Tigers. Berlin [Germany]: 15-16 November 2002.

Ojuland, Kristiina. Address to the Riigikogu on Behalf of the Government of Estonia. Tallinn [Estonia]: 8 June 2004.

Ojuland, Kristiina. Address at the Conference "New Europe 2020": "The New Role of Governments and the EU in Wider Europe." 27 August 2004.

Ojuland, Kristiina. Address at the Event "Dialogue with a New Member State: Estonia." Vienna [Austria]: 28 September 2004.

Parts, Juhan. Speech on the Occasion of the 86th Independence Day. Tartu [Estonia]: 23 February 2004. 
Parts, Juhan. Speech at the European People's Party Congress. Brussels [Belgium]: 5 February 2004.

Parts, Juhan. Speech in Valga. Valga [Estonia]: 21 May 2004.

Parts, Juhan. Speech in Natolin: Competition and Competitiveness in Europe. Warsaw [Poland]: 29 September 2004.

Parts, Juhan. Lecture at the University of Glasgow. Glasgow [United Kingdom]: 18 October 2004.

Parts, Juhan. Speech on the Role of Estonian Lawyers at the $28^{\text {th }}$ Estonian Lawyers' Days. Tartu [Estonia]: 22 October 2004.

Parts, Juhan. Speech at the Norwegian Nobel Institute. Oslo [Norway]: 15 February 2005.

Rüütel, Arnold. Address at St John's College of Oxford University. Oxford [United Kingdom]: 12 November 2002.

Rüütel, Arnold. TV Address on the Eve of Referendum. Tallinn [Estonia]: 13 September 2003.

Rüütel, Arnold. Signing of the EU Accession Treaty in Athens. Athens [Greece]: 16 April 2003.

Rüütel, Arnold. Remarks at the Flag-Raising Ceremony to Mark in front of Kadriorg Palace. Tallinn [Estonia]: 1 May 2004.

Tarand, Indrek. Partnership for Peace and Confidence Building in Europe. Helsinki [Finland]: 4 May 1994.

Velliste, Trivimi. Speech at the NUPI-CSIS Conference on Baltic and Nordic Security. Oslo [Norway]: 21 September 1993. 


\section{Other sources:}

The webpage of the President of the Republic of Estonia, www.president.ee

- $\quad$ Name Them and Remember. The Economist, 20 September 2007.

The webpage of the Estonian Government, www.valitsus.ee

- The Government Designates a Memorial Day for the Holocaust and Other Victims of Crimes Against Humanity. Tallinn, 6 August 2002.

- Prime Minister Ansip handed over Estonian support for establishing the Virtual Museum of Communist Crimes. Washington, 29 November 2007.

- Estonia Becomes Member of Task Force for International Cooperation on Holocaust Education, Remembrance and Research. 5 December 2007.

- Estonian Institute of Historical Memory. 04 October 2010.

The webpage of the European Commission:

http://ec.europa.eu/enlargement/archives/enlargement_process/past_enlargements/eu10/esto nia_en.htm (last accessed 26.04.2011).

The webpage of the Estonian National Electoral Committee:

http://www.vvk.ee/varasemad/?v=rh03 (last accessed 26.04.2011)

The World Factbook:

https://www.cia.gov/library/publications/the-world-factbook/geos/en.html (last accessed 26.04.2011)

Eurobarometer, 2003 Spring - Comparative Highlight Report:

EUROBAROMETER EB59 — CC-EB 2003.2. 